\title{
What Do State-Owned Development Banks Do? Evidence from BNDES, 2002-09
}

\section{Citation}

Lazzarini, Sergio G., Aldo Musacchio, Rodrigo Bandeira-de-Mello, and Rosilene Marcon. "What Do State-Owned Development Banks Do? Evidence from BNDES, 2002-09." World Development 66 (February 2015): 237-253.

\section{Published Version}

http://www.sciencedirect.com/science/article/pii/S0305750X1400254X

\section{Permanent link}

http://nrs.harvard.edu/urn-3:HUL.InstRepos:15786565

\section{Terms of Use}

This article was downloaded from Harvard University's DASH repository, and is made available under the terms and conditions applicable to Open Access Policy Articles, as set forth at http:// nrs.harvard.edu/urn-3:HUL.InstRepos:dash.current.terms-of-use\#OAP

\section{Share Your Story}

The Harvard community has made this article openly available.

Please share how this access benefits you. Submit a story.

Accessibility 
Sergio G. Lazzarini

Insper Institute of Education and Research

R. Quatá, 300

São Paulo, SP Brazil 04546-042

Phone: 55-11-4504-2432

E-mail: SergioGL1@insper.edu.br

\author{
Aldo Musacchio \\ International Business School-Brandeis University, \\ Harvard Business School, \\ and the National Bureau of Economic Research \\ 415 South Street MS 032 \\ Waltham, MA 02453 \\ Phone: 781-736-2249 \\ E-mail: aldom@brandeis.edu \\ Rodrigo Bandeira-de-Mello \\ Getulio Vargas Foundation (FGV-EAESP) \\ R Itapeva 47411 Andar \\ Bela Vista \\ São Paulo, SP Brazil 01332-000 \\ Phone: 55-11-3799-7740 \\ E-mail: rodrigo.bandeira.demello@fgv.br \\ Rosilene Marcon \\ Universidade do Vale do Itajaí (UNIVALI) \\ Rua Uruguai, 458 \\ Itajai, SC Brazil 88302-202 \\ Phone: 55-47-3341-7534 \\ E-mail:rmarcon@univali.br
}

This version: August 2014 


\title{
What Do State-Owned Development Banks Do? Evidence from BNDES,
}

\section{2-2009}

\begin{abstract}
Defendants of state-owned development banks emphasize their role in reducing capital constraints and fostering productive investment; detractors point out that they may benefit politically connected capitalists or bail out inefficient firms. We study the effect of loans and equity investments of the Brazilian National Development Bank (BNDES) and find that they do not have any consistent effect on firm-level performance and investment, except for a reduction in financial expenditures due to the subsidies accompanying loans. However, BNDES does not systematically lend to underperforming firms. Our results indicate that BNDES subsidizes firms that could fund their projects with other sources of capital.
\end{abstract}

Keywords: state-owned banks, development banks, industrial policy, political connections,

\section{BNDES}

JEL codes: H1, O16, O25, L3 


\section{Acknowledgments}

Research assistance was ably provided by Cláudia Bruschi, Diego Ferrante, Marina Gama, Carlos Inoue, Gustavo Joaquim, Jefferson Lana, Daniel Miranda, and André Leonardo Pruner da Silva. We are grateful for our useful discussions with Patrick Behr, Ricardo Brito, Vinicius Carrasco, Carlos Cinelli, Mariano Cortes, Rohit Deshpandé, Elizabeth Farina, Erik Feijen, Cláudio Ferraz, Marcio Garcia, Catiana Garcia-Kilroy, Martin Goetz, Emanuel Kohlscheen, Lakshmi Iyer, Alain Ize, Joao Manuel P. de Mello, Walter Novaes, Carlos Saiani, Marcelo Santos, Jordan Siegel, Rodrigo Soares, Augusto de la Torre, Lou Wells, and Eric Werker and for comments by seminar participants at the Harvard Business School, INSEAD, Tilburg University, PUC-Rio, Universidad de Desarollo, University of Illinois at Urbana Champaign, the World Bank, the Central Bank of Brazil, and three anonymous reviewers. Aldo Musacchio and Sergio Lazzarini thank the Harvard Business School, Insper, and CNPq for their financial support. All interpretations and remaining errors are the responsibility of the authors. 


\section{Introduction}

This paper studies the implications of long-term credit provided by state-owned development banks. Such banks are financial intermediaries that specialize in providing long-term credit - usually subsidized — to promote industrialization or infrastructure projects (Armendáriz de Aghion, 1999). Different from multilateral banks, state-owned development banks are controlled by national governments and generally have a mandate to support local business activity. These banks have been credited with a central role in the financing of industrialization in East Asia, Latin America, and Europe (e.g. Amsden, 2001; Aronovich \& Fernandes, 2006; Cameron, 1961; Rodrik, 2004) and are still important suppliers of credit in emerging and even developed markets. In 2012, Germany's KfW, Brazil's BNDES, and the China Development Bank had outstanding loans representing, respectively, $15.5 \%, 11.3 \%$, and $12.4 \%$ of their countries' GDP (Ferraz, Além, \& Madeira, 2013).

Yet, despite their size and importance, we do not have a clear understanding of what development banks do in practice. Although there is a large literature examining state-owned banks (Cole, 2009; Dinç, 2005; Khwaja \& Mian, 2005; La Porta, Lopez de Silanes, \& Shleifer, 2002), development banks are a peculiar and understudied type of lender. Unlike state-owned commercial banks, which tend to provide generalized lending similar to that of private banks, development banks specialize in long-term lending to promote new industries and firms. In other words, such banks are supposed to have specialized competencies and a clear mandate to spur industrial development (e.g. Armendáriz de Aghion, 1999). Yet we have few studies examining their behavior in detail. Most of the work on development banks and their relationship to industrial policy is either theoretical (Amsden, 1989; Armendáriz de Aghion, 1999; Aronovich \& Fernandes, 2006; Bruck, 1998) or based on qualitative case studies of developing or newly industrialized countries (Amsden, 1989, 2001; Fordwor, 1981; Ndongko, 1975; Rodrik, 2004). 
In this paper, we use firm-level evidence from Brazil to examine what happens when development banks target local firms and the factors that can explain how banks allocate their loans to and investments in such firms. Brazil offers a good laboratory for this inquiry because the Brazilian National Bank for Economic and Social Development, known as BNDES for its Portuguese acronym, is one of the largest development banks in the world. Founded in 1952 to provide long-term credit for infrastructure projects, BNDES soon became a central venue for the capitalization of domestic and foreign groups investing in Brazil (Leff, 1968). Despite Brazil's privatization wave in the 1990s, BNDES remains an important source of capital in the economy; its loans represent more than $20 \%$ of the total credit to the private sector (Figure 1) and the bulk of the long-term credit. We thus built a unique database of firm-level loans and equity investments by BNDES, based on the annual reports of 286 firms publicly traded in BM\&F Bovespa, the São Paulo Stock Exchange, between 2002 and 2009. We rely on publicly traded firms because, for confidentiality reasons, BNDES - like other development banks (Nelson, 2001)—does not disclose firm-level loan data. Yet we manage to obtain a non-negligible sample of firms accounting for around $31 \%$ of the outstanding loans and $69 \%$ of the total equity held by BNDES in 2009.

[Figure 1 around here]

Using this micro-level data, we test a set of hypotheses emanating from two competing views on the role of public banks. According to the industrial policy view, development banks specialize in providing long-term capital and lending to companies that would not undertake projects if it were not for the availability of long-term, subsidized funding (Bruck, 1998; Yeyati, Micco, \& Panizza, 2004). In economies with significant capital constraints, development banks can alleviate capital scarcity and promote entrepreneurial action to boost new or existing industries (Armendáriz de Aghion, 1999; Cameron, 1961; Gerschenkron, 1962). In such circumstances, we 
would expect to see the borrowing firms increasing their capital investments and overall profitability, on average, after they get funding. In contrast, the political view sees lending by development banks causing multiple sources of credit misallocation for at least two reasons. The soft-budget constraint hypothesis (e.g. Kornai, 1979) suggests that development banks may bail out companies that would otherwise fail. The rent-seeking hypothesis argues that politicians create and maintain state-owned banks not to channel funds to socially efficient uses, but rather to maximize their own personal objectives or to engage in crony deals with politically connected industrialists (Ades \& Di Tella, 1997; Faccio, 2006; Hainz \& Hakenes, 2008; La Porta et al., 2002).

A large literature has examined the lending behavior of state-owned banks, with results that are generally aligned with the political view (e.g. Dinç, 2005; Sapienza, 2004). ${ }^{1}$ The general conclusion of this literature is that state-owned banks may misallocate credit by targeting firms based on political criteria rather than on the merits of the specific projects. Yet these studies analyze state-owned commercial banks and do not assess other outcomes targeted by development banks, such as industry- or firm-level investment. Although development and state-owned commercial banks should be subject to the same types of political pressure, development banks display a distinct dynamic because they are usually involved in large-scale industrial projects. Given the more complex nature of those projects, development banks may bring benefits as well as potential distortions not completely examined in the extant literature on state-owned banks.

Our emphasis on firm-level data allows us to examine more directly the effects predicted by both the industrial policy and the political views (e.g., changes in performance and investment activity, controlling for other sources of firm-level heterogeneity). Furthermore, even if development banks have the mandate to promote industrial development in general, much of the lending activity tends to occur at the firm level. As it turns out, using fixed-effect panel regressions, we do not find any consistent increase in profitability, market valuation (Tobin's q), or investment amongst the firms receiving funds from BNDES, either as debt or equity. However, 
BNDES loans do significantly reduce these firms' financial expenses due to the accompanying subsidies. These conclusions hold when we perform differences-in-differences matching analysis (Abadie, Drukker, Herr, \& Imbens, 2004; Abadie \& Imbens, 2011) in order to more adequately build treatment and control groups with and without an increase in BNDES loans. The effect of the subsidized loans seems to be, therefore, a simple transfer from the government to the shareholders of the borrowing firms. In sum, our analysis does not support the industrial policy view of development banks.

As suggested by the political view, a potential explanation for this result is that BNDES is systematically selecting underperforming firms with poor investment opportunities. We do not find, however, that this is happening. Employing fixed-effect regressions using firm-level data on loans and equity allocations received from BNDES as dependent variables, we show that past financial performance tends to moderately increase the likelihood of receiving a loan. Thus, it is not the case that BNDES is systematically supporting or bailing out bad firms. Yet, consistent with the political view, we show that the political market matters. Following previous research (Bandeira-de-Mello \& Marcon, 2005; Boas, Hidalgo, \& Richardson, 2014; Claessens, Feijen, \& Laeven, 2008), we measure political connections using data on firm-level campaign donations. To avoid endogeneity bias, we not only separate donations for candidates who win and lose the election, but also focus on candidates who won or lost by a small margin (Arvate, Barbosa, \& Fuzitani, 2013; Boas et al., 2014). We find that firms that donate to winning candidates are more likely to receive funding in the form of loans from BNDES.

Thus, although political criteria are apparently influencing which companies will be targeted, we do not find a negative selection of underperforming firms. An explanation is that good and bad firms alike want to benefit from governmental subsidies; in our database, both profitable and unprofitable firms appear to be donating to political candidates. Therefore, our findings suggest a new form of credit misallocation that has received scant attention in the literature on state- 
owned banks and, in particular, on development banks. Such banks may target firms that want to benefit from subsidies but that could fund their projects with other sources of capital (e.g. Antunes, Cavalcanti, \& Villamil, 2012; Cull, Li, Sun, \& Xu, 2013). ${ }^{2}$ If development banks channel subsidized credit to firms with higher capacity to repay their loans, then private banks may become reluctant to cater to smaller, higher-risk firms, which are relatively more affected by failure in credit markets (Colombo, Giannangeli, \& Grilli, Forthcoming).

A caveat, however, is that we focus only on profitability and investment; we do not assess whether allocations support social initiatives or yield externalities that are not measured in our database (such as industry-level spillovers resulting from firm-level investment). We also focus on a subset of firms traded on the stock exchange, which tend to be larger and less financially constrained than the overall population of firms receiving BNDES loans or equity. ${ }^{3}$ In addition, lending to firms that can repay their loans has the benefit of reducing default rates. Indeed, BNDES's rate of nonperforming loans has been very low; in 2010, it was only $0.15 \%$ of total loans; in 2013, the rate was even lower, $0.01 \%$ (BNDES, 2013) and much below the average rate of all Brazilian banks by the same period $(3 \%) .{ }^{4}$ In other words, focusing on large firms may reduce the actual effect on performance and investment (given that the borrowing firms could borrow elsewhere) but also guarantees lower credit risk. For these reasons, our results should only be taken as a preliminary indication of a potential source of misallocation. Nevertheless, studies performed by governmental research agencies using larger datasets including non-listed firms (which are not disclosed to independent researchers) have also failed to show that BNDES loans have consistent productivity-enhancing effects. $^{5}$

Our paper is structured as follows. In the next section, we provide a brief historical account of BNDES. We then describe our data on BNDES's allocations and outline our hypotheses, building on the industrial policy and political views of development banks discussed before. We next present and discuss our econometric results. Concluding remarks follow. 


\section{State-Owned Development Banks and the Experience of BNDES}

In his study of state intervention in the banking system, Gerschenkron (1962) argues that, without public participation, lack of trust among creditors and debtors would inhibit deepening credit markets. According to this view, private banks are reluctant to give credit to long-term, risky investments, leaving value-enhancing projects unfunded (Bruck, 1998). Armendáriz de Aghion’s (1999) model refines this argument by proposing that private banks underinvest in the expertise required to evaluate and promote new industries for the long run. In other words, development banks differ from traditional state-owned banks because they specialize in long-term industrial development. In late-industrializing economies, Amsden (1989) argues, development banks were instrumental not only as a means to infuse long-term capital into industry, but also as a mechanism to screen good private projects, establish well-defined performance targets, and monitor the execution of investments.

Our study provides a detailed analysis of Brazil's BNDES, one of the largest and most profitable development banks in the world. The government of Brazil created the Brazilian National Bank of Economic Development (BNDE) in 1952, when a joint Brazil-United States Development Commission — made up of engineers and technocrats from Brazil, the United States, and the World Bank - recommended the creation of a development bank to improve and renew Brazil's energy and transportation infrastructure. This initial focus was then expanded to include financial support to a host of industries that the government wanted to develop, such as metals, oil, chemicals, and cement (Campos, 1969; Leff, 1968).

By focusing on long-term loans, the bank was trying to fill a void in Brazil's financial markets. The government created BNDE because the financing mechanisms firms used to finance the country's early industrialization — private bonds and equity markets— had practically disappeared in the 1930s when the government imposed interest-rate ceilings and inflation reached two digits (Musacchio, 2009). By the time BNDE was created, the stock of long-term loans had 
declined from close to 20\% of GDP in 1914 to below 2\% in the 1950s (Musacchio, 2009). From early on, BNDE was established as an isolated entity with a technical staff, not only to promote industrial development (in line with the argument by Armendáriz de Aghion, 1999) but also to protect the bank's bureaucracy from political cronyism. Yet President Vargas did this while simultaneously building a political system based on strong corporatism, with newly created unions and business groups playing an important role (see e.g. Nunes, 1997; Schneider, 1991).

During its first decade, BNDE focused on providing long-term funding for the renewal (reaparelhamento) of the railway system and the construction of new hydroelectric power plants. Most of the large projects BNDE financed were carried out by large state-owned enterprises such as Furnas and Cemig (Tendler, 1968). Yet by the late 1950s, the bank's focus began to switch to supporting the development of the still infant steel industry. In fact, BNDE served as a holding company for a variety of steel companies and ended up financing $70 \%$ to $80 \%$ of all capital investments in the steel industry (BNDES, 2002). During the 1950s and 1960s, BNDE provided long-term loans with interest rates below the inflation rate (Curralero, 1998).

After the 1960s, during the military government (1964-1985), BNDE changed its focus from lending to public projects to financing private groups that were developing new industries or new technologies that would help substitute expensive imports. The bank created three subsidiaries that allowed it to finance the sale of machinery and equipment with high national content domestically and abroad, provide capital to machinery and equipment manufacturers, and provide growth capital for the private sector, especially in the chemicals and consumer goods industries (BNDES, 2002; Najberg, 1989).

With the oil shock of 1979 and the debt crisis of 1982, BNDE became a financial institution, financing the restructuring of state-owned enterprises and bailing out private firms through equity investments (and, in some cases, loans). In 1982, the bank added the objective of social development to its mission—changing its acronym from BNDE to BNDES ("S" standing for 
“social") — and merged all of its equity investment programs into a new equity arm called BNDES Participações (BNDESPAR). After the creation of BNDESPAR, the bank increased the share of total capital it allocated to equity investments, partly because it capitalized troubled private firms and partly because the equity business allowed the bank to hedge against the high inflation of the 1980s. The loan business, in fact, suffered great losses as its subsidized interest rates trailed behind inflation (Curralero, 1998). Yet, Villela (1995) calculates that BNDES loans extended to finance new capital formation in the 1980 s accounted for $4 \%$ to $6 \%$ of the total gross capital formation in Brazil, its lowest point since the 1950s.

BNDES survived the 1980s and had to reinvent its mission during the privatization wave of the 1990s, especially under the term of President Fernando Henrique Cardoso (1995-2002). The bank was actually an active participant in the reform process of the 1990s: It planned and executed privatizations, provided acquirers with loans, and purchased minority stakes in several former stateowned enterprises. Moreover, the bank's equity business became its most profitable business line and helped Brazilian firms finance capital investments during the 1990s, when financial markets were still shallow (Musacchio \& Lazzarini, 2014). In the two administrations of President Luiz Inácio Lula da Silva (2003-2010), BNDES was also involved in several large-scale operations and helped orchestrate mergers and acquisitions to build large "national champions" in several industries (Almeida, 2009; Lazzarini, 2011). Around 60\% of the bank's total loans target large firms with annual revenues higher than US\$ 130 million (BNDES, 2013).

Therefore, BNDES's more recent role in the Brazilian economy is not as clear as it had been in the postwar period. With stock markets growing rapidly after 2003 and with Brazil experiencing the biggest capital inflows since before World War I, many Brazilian firms, especially the largest ones, were probably not as financially constrained as in the 1990s. Those firms, critics argued, could borrow funds elsewhere. Inoue, Musacchio, and Lazzarini (2011) show that minority equity investments during the 1990s helped firms to expand capital expenditures, especially firms with 
capital constraints, but that the effect disappeared after the turn of the century, when capital markets experienced rapid growth. For instance, between 1995 and 2009, stock market capitalization to GDP in Brazil jumped from 19\% to 73\%. Some critics also argued that supporting firms in traditional established sectors such as oil, mining, and agribusiness was inconsistent with the objective of generating positive externalities in the form of learning and technological diversification (Almeida, 2009).

Another common criticism of BNDES is that the bulk of its funds come from payroll taxes transferred by the government - the Fundo de Amparo ao Trabalhador (FAT). These funds are transferred to BNDES in perpetuity and receive in return a subsidized rate, known as TJLP (the Portuguese acronym for "federal long-term interest rate"), which is set below the market rate and which is also the rate at which BNDES lends (Prochnik and Machado, 2008). Moreover, after 2002, the proportion of BNDES funding coming directly from the Treasury increased significantly. Those funds were financed with new public debt, for which the government had to pay market rates above the subsidized TJLP rate charged by BNDES in its loans. Although some claimed the additional tax income generated from new investments could compensate for the subsidized rates (Pereira, Simões, \& Carvalhal, 2011), others noted that Treasury transfers were increasing public debt and that future fixed capital formation could come from private sources of capital (Lamenza, Pinheiro, \& Giambiagi, 2011).

Our database, discussed next, covers the period 2002-2009 and sheds more light on the process by which BNDES selects firms and affects their performance-if indeed it does affect firm performance. Unfortunately, we were unable to collect data on loans before 2002. Therefore, our data cover the more recent period in which BNDES expanded simultaneously with a more favorable context in which firms could fund their operations through local or foreign capital markets. Yet our empirical context should by no means be interpreted as being unable to tell us something about BNDES's impact on the economy as a whole. As shown in Figure 1, BNDES's credit operations to 
GDP have increased steadily since 2002 and remained important even several years after the financial crisis of 2008. Examining the bank in a period during which it had increased presence in the Brazilian economy allows us not only to assess its performance but also to inform the current debate on the implications and selection criteria of development banks. We would like to assess whether BNDES's loans and equity are changing firm-level performance and investment, as predicted by the industrial policy view of development banks, or whether the selection of its targets is affected by the types of distortion suggested by the political view.

\section{Data and Hypotheses}

\subsection{Data}

To assess the performance implications and selection criteria of BNDES, we collect panel data from 286 publicly listed companies in the São Paulo Stock Exchange (BM\&F Bovespa) between 2002 and 2009. We used multiple sources to build our main variables. Basic financial information came from Economática, a financial database, while ownership data were obtained from diverse sources such as the Brazilian Securities and Exchange Commission (CVM) and Valor Grandes Grupos (a yearly survey of Brazilian business groups). We cleaned the database by eliminating inconsistent information (such as cases in which total assets were different from total liabilities) and winsorized at the $1 \%$ and $99 \%$ percentiles some key performance variables, such as return on assets and Tobin's q, that were shown to vary substantially. Missing information for some variables and years causes the number of firms in the panel to vary according to the model specification. We also dropped from our database financial firms and publicly listed holding corporations - keeping only their listed affiliates.

We collected data on BNDES loans and equity in two ways. In the case of loans, we analyzed companies' balance sheets in detail, trying to find explanatory notes indicating the origin and yearly composition of outstanding loans. More recently, BNDES started disclosing data on approved projects; however, for confidentiality reasons, the bank does not provide historical data on 
firm-level loans. Still, because most publicly listed companies report the name of the lender and/or the interest rate associated with a loan, we were able to collect data for a large number of firms and years. As noted before, loans originated from BNDES — supplied directly by the bank or indirectly through another financial intermediary - are associated with a subsidized long-term interest rate, TJLP. ${ }^{6}$ Thus, yearly information on BNDES loans was collected based on cases in which the company reported either that the loan came from BNDES or that the associated interest rate was based on TJLP. If the firm did not specify the origin of its loans or their interest rates, we considered that information on BNDES loans for that particular company was missing.

As for BNDES equity, we observed the ownership composition of each firm to identify cases in which BNDES — through its investment arm, BNDESPAR — appeared as an owner. We then collected the percentage of BNDES's equity ownership. We focused on direct ownership relations only; that is, cases in which BNDES was a direct owner of the firm rather than an indirect owner through a pyramidal ownership structure (for example, BNDES owns an intermediary firm which owns the observed company). We have two reasons for our focus on direct ownership. First, we were interested in computing the size of equity participation, which becomes much more difficult when opaque pyramids are involved. Second, Inoue et al. (2013), comparing direct and indirect stakes, report that the most consistent performance effects of BNDES equity comes from direct ownership. Thus, our focus on direct equity seems to be appropriate for capturing the effect of BNDES ownership as well as their magnitude.

Table 1 shows descriptive data on the number of firms in the database observed with BNDES loans and equity. Many more firms have BNDES loans than have BNDES equity, although the participation of the bank as an owner has increased over the years. The modal firm in our database of firms with BNDES loans has around $31 \%$ of its debt coming from the bank; in the case of equity, the modal firm has around $14 \%$ of BNDES direct ownership. Our final sample corresponds to around $31 \%$ of total outstanding loans and $69 \%$ of total equity held by BNDES in 
2009. Thus, while we focused on publicly listed firms, our sample represents a substantial fraction of BNDES's loans and equity. ${ }^{7}$ In addition, although $84.5 \%$ of firms with BNDES equity also have BNDES loans, most of the firms with BNDES credit (87.9\%) are not owned by the bank. The correlation between the size of observed BNDES loans and equity is only 0.149 . This allows us to simultaneously examine the effect of both loans and equity positions on firm-level performance variables.

[Table 1 around here]

\subsection{Variables}

We use four sets of variables (see Table 2). The first set includes variables related to firmlevel performance and investment activity. Thus, the profitability of firms is measured by ROA (net return on assets) and EBITDA/Assets (operational return on assets). The latter is particularly important because the subsidy associated with BNDES loans may distort an analysis of profitability through ROA. We use a simplified proxy of Tobin's q (market value of stocks plus debt divided by total assets) to measure the performance of firms as assessed by the stock market. Because, as noted before, BNDES loans may help reduce the cost of capital, we add the variable Finex/Debt, measuring the ratio of firm-level financial expenses (loan payments) to debt. Two more variables are related to investments: Capex/Assets and Fixed assets/Assets measure, respectively, yearly capital expenditures and the total stock of fixed capital relative to the stock of all existing assets.

[Table 2 around here]

The second set of variables corresponds to BNDES loans and equity. We measure these variables in both absolute and relative (percentage) terms. Thus, Ln(BNDES loans) and 
Ln(BNDES equity) measure the total (logarithmic) value of loans and equity positions. (In the case of equity, we considered the book value of equity times the percentage participation of BNDES.) \%BNDES loans and \%BNDES equity, in turn, gauge the extent of BNDES capital relative to total debt and total equity, respectively.

The third set of variables is related to the political environment. Numerous studies have found that, in Brazil, political campaign financing is a crucial mechanism through which firms establish political connections. Large election districts and an open-list competition create incentives for politicians to trade "pork" for private money to support costly campaigns (Samuels, 2002). Brazilian corporations, unlike those in the United States, can make cash donations directly to candidates and there is no restriction on donations from a foreign firm, provided it has a local subsidiary. The official limit for domestic firms is two percent of their gross revenues, but "under the table" donations are pervasive (Araújo, 2004). Furthermore, collective lobbying efforts, although widespread, are perceived to be less effective than individual connections. The lack of strong associations, capable of controlling free-riding, pushes firms to establish their own political ties (Schneider, 2004). Consistent with this logic, several empirical studies have found a significant association between campaign donations for Brazilian politicians and firm-level profitability (Bandeira-de-Mello \& Marcon, 2005), preferential finance (Claessens et al., 2008), and access to government contracts (Arvate et al., 2013; Boas et al., 2014).

In Brazil, candidates are required to disclose all donors to the Superior Electoral Tribunal. The electoral authorities then release data on election finances for each candidate. We used this data to match individual firm contributions to politicians with election results. Thus, for each firm, we have the number of candidates (running for president, senator, state governor, or state or federal deputy) to whose campaign the firm officially contributed in the previous election. Given that our panel runs from 2002 to 2009, we consider campaigns that occurred in 2002 and 2006. Thus, data from the 2002 campaign are used to assess outcomes that occurred in 2003 through 2006, while 
data from the 2006 campaign are used to assess outcomes that occurred in 2007 through 2009. In line with previous studies, we consider campaign donations as a sign of the extent of a firm's political activity, even if "under the table" donations are common.

Because donation data may be plagued with self-selection issues-for example, the best firms may be approached by the most candidates - we use a number of refinements in our measure. We first distinguish donations to candidates who won the election from donations to those who lost, considering that election results have an exogenous component due to random events affecting political competition (Claessens et al., 2008). Yet, although landslide victories are infrequent in Brazil (Boas et al., 2014), some firms may bet on particular candidates with higher chances of victory. We therefore consider only candidates who won or lost the election by a small margin (Arvate et al., 2013; Boas et al., 2014; Caughey \& Sekhon, 2011). For elections involving majority rule — for president, senator, and state governor — we consider the margin of victory in terms of percentage of total votes. Specifically, we adopt in our regressions three distinct margins of victory: $2 \%, 5 \%$, and $10 \%$ of total votes. Elections for the Chamber of Deputies (at the federal and state levels) are more complicated because winning is based on a proportional list of votes. Based on the estimated distribution of votes presented in Boas et al. (2014), we consider the margin of victory for deputies in terms of number of votes: 10,000, 25,000, and 100,000.

Finally, we use a set of control variables. Because membership in business groupsdiversified conglomerates in emerging markets-is argued to affect firm-level performance (Khanna \& Yafeh, 2007), we add a dummy variable coding whether or not the firm belongs to a group. Variations in the size of the firm are captured by the variable $\operatorname{Ln}($ Assets), the logarithmic value of total assets. Leverage (debt to assets) and Fixed (fixed assets to total assets) capture, respectively, variations in terms of debt activity and propensity to engage in fixed allocations. When Fixed is used as a dependent variable, it is omitted as a control. The last control, Foreign, is a dummy variable indicating whether or not the firm is foreign-controlled. ${ }^{8}$ 


\subsection{Hypotheses}

Based on our earlier discussion of the industrial policy and political views on the role of development banks, Table 3 summarizes our main hypothesized effects. To tease out alternative explanations, we examine not only BNDES's effects on performance and investments, but also factors that may affect BNDES's allocations - that is, the amount of loans or equity that a firm receives from BNDES.

[Table 3 around here]

The industrial policy view rests on the assumption that development banks operate in environments with capital scarcity. By specializing in long-term finance neglected by the private sector, development banks facilitate the execution of valuable investments and projects that would not otherwise be carried out (e.g. Armendáriz de Aghion, 1999; Bruck, 1998; Yeyati et al., 2004). Development banks may also set high standards for firms and subject them to performance targets conditional on their allocated capital (Amsden, 2001). Thus, according to this view, development banks should improve firms' investment and performance. For instance, if firms are constrained in their long-term financing, loans from development banks may allow them to undertake capital expenditures to capture economies of scale or acquire new technology. This should be expressed as improved firm-level profitability (ROA, EBTIDA/Assets) or market valuation (Tobin's q). Of course, an increase in profitability may be due to subsidized funding (that is, a reduction in Finex/Debt). However, if development banks' allocations really do prompt investment in valuable projects, then the effect on performance should go beyond a reduction in interest payments. Following the same logic, BNDES allocations should also positively affect capital expenditures and the stock of fixed capital, whose longer-term horizon may require extended loans or equity allocations not easily found in scarce capital markets. 
As for the determinants of allocations, the industrial policy view offers no clear prediction. On the one hand, development banks may pick firms with good performance in order to guarantee repayment or to boost new investment based on realized capabilities (Amsden, 2001). On the other hand, development banks may influence firms with latent advantages; that is, firms with valuable projects and activities that were not sufficiently developed due to lack of capital and complementary investments (e.g. Lin \& Chang, 2009; Rodrik, 1995). If those advantages are latent, development banks may not necessarily target firms with superior performance-past or current.

The political view, in contrast, places higher emphasis on the selection process.

Governments can use their development banks to bail out failing corporations (the soft-budget constraint hypothesis) or benefit politically connected capitalists (the rent-seeking hypothesis). Indeed, one way political connections translate into preferential access to finance is through state banks. In this case, the government uses its control of the country's scarce financial resources to bargain for political support and for politicians' private interests. As discussed earlier, campaign donations in Brazil have been shown to have implications for preferential finance (Claessens et al., 2008). Well-connected industrialists may therefore have superior ability to attract loans or equity from development banks, even if they can get capital elsewhere (Ades \& Di Tella, 1997; Haber, 2002; Krueger, 1990).

Because, according to this view, allocations may be driven for reasons other than efficiency, there is no clear prediction on the effect of a development bank's loans or equity on firm-level performance or investment. Claessens et al. (2008) even suggest that poorly performing firms will have incentives to make political connections so as to benefit from governmental support and protection. Thus, in our database, the only clear positive effect from allocations (in particular, loans) should be associated with a reduction in interest payments thanks to subsidized credit. However, in this case, the loans are simply a transfer from the bank to capitalists, without necessarily having any positive effect on business-level activity. In other cases, governments can 
use state credit to support the creation of national champions-large firms competing in global markets (Ades \& Di Tella, 1997; Falck, Gollier, \& Woessmann, 2011). Examining patterns of global expansion, however, is beyond the scope of this paper.

In the next section, we test these hypotheses through two sets of regressions. The first set examines the impact of BNDES allocations on firm-level performance and investment; the second set assesses the determinants of allocations (that is, it uses BNDES loans and equity as dependent variables and performance and political factors as independent variables). In both cases, we use fixed-effects specifications, including time-invariant firm-level fixed effects and time-varying year and industry-year effects, to control for unobservables. ${ }^{9}$ Thus, we fundamentally measure how variations in BNDES's allocations affect variations in firm-level performance, and vice-versa. We also complement our analysis with several robustness checks, including differences-in-differences estimation with matching.

\section{Results and Discussion}

\subsection{Descriptive analysis}

The first important pattern that comes out of our data is that the cross-sectional variation does show that firms that receive BNDES loans are larger and exhibit superior performance in terms of higher ROA, higher EBITDA/Assets, and lower Finex/Debt (see Table 4). Although the latter may have to do with loan subsidies, from a cross-sectional standpoint it seems that BNDES loans are associated with superior operational performance (net of financial expenses). Firms receiving loans also appear to have a larger proportion of fixed assets. At first glance, this seems to be consistent with the industrial policy view that development banks are associated with improved investment and performance.

[Table 4 around here] 
When we look at firms in which BNDES buys equity, we do not find so clear a crosssectional pattern. Firms with BNDES equity allocations have lower EBITDA/Assets, but are also larger and apparently have a larger proportion of fixed assets. We note, however, that the number of firms with BNDES equity in our sample is much smaller than the number of firms with BNDES loans, which limits the generalization of our results.

\subsection{Impact of BNDES allocations on performance and investment}

Table 5 presents fixed-effects regression results on how BNDES affects firm-level performance (ROA, EBITDA/Assets, and Tobin's q). We include loan- and equity-based variables measured in two ways (absolute logarithmic value and percentage) as well as, in some specifications, lagged values to accommodate possible phased effects of the allocations. In virtually all model specifications and for all performance variables, we find no significant effect for the BNDES variables. Thus, although BNDES appears in a cross-sectional examination to be lending to the best firms, the effect disappears once we control for firm- and industry-level factors. Our data are thus inconsistent with the industrial policy view, which argues that loans from development banks improve firms' performance by allowing them to invest in valuable projects that would otherwise go unfunded. Once we control for particular industry- and firm-level traits, we find that BNDES allocations have no particular effect on profitability or market valuation.

[Table 5 around here]

As expected, the first four columns in Table 6 show that BNDES loans have a negative effect on financial expenses. The subsidy included in BNDES loans reduces firms' cost of capital. Consider the results of Column 2: Because the marginal impact of BNDES loans is simply the estimated coefficient of $\operatorname{Ln}$ (BNDESloans) divided by the size of BNDES loans and the dependent variable measures financial expenses relative to assets, the marginal reduction of financial expenses 
for each additional dollar from BNDES can be computed as the estimated regression coefficient divided by the participation of BNDES loans on total debt—which is 0.303 , on average, for the firms with observed loans from BNDES. Thus, each additional dollar from BNDES reduces financial expenses (relative to debt) by $0.04(0.013 / 0.303)$, or $4 \%$. Column 4 , on the other hand, shows that a one-percentage-point increase in BNDES loans relative to debt (lagged) reduces the ratio of financial expenses to debt by 0.12 percentage point $(p<0.01)$. Thus, our estimates indicate that BNDES loans reduce the cost of capital by a percentage differential somewhere between $4 \%$ and $12 \%$, which is more or less consistent with the subsidy included in BNDES's interest rates.

The results of Column 4 also show that a one-percentage-point increase in BNDES equity participation (lagged) reduces the firm's financial expenses to assets by 2.1 percentage points $(p<$ 0.001). A possible explanation is that creditors see extra equity from BNDES as an implicit guarantee of repayment. These results are consistent with both the industrial policy and the political views, given that governmental allocations may affect the cost of capital directly through subsidies or indirectly through implicit guarantees.

Table 6 also shows that there is a significant effect of BNDES loans on the ratio of capital expenditures to assets. However, results are not very consistent across specifications. There is a positive effect once we consider the logarithmic value of loans (Column $6, p<0.05$ ), but if we take the ratio of BNDES loans to the firm's total debt (Column 7), the effect becomes negative, although with moderate significance $(p<0.10)$. As for the effect of BNDES loans and equity on the ratio of the stock of fixed capital to assets, we find no significant result, except for a marginally significant negative of $\%$ BNDES loans $t$ in the last column $(p<0.10)$. Thus, our results provide, at best, only weak support for the industrial policy view. In our sample, BNDES loans and equity investments do not consistently change firms' investment decisions once we control for a host of firm-level factors. 
[Table 6 around here]

\subsection{Robustness check: Differences-in-differences matching analysis of performance and investment}

We now present a battery of tests to check the robustness of our results and assess alternative model specifications. Given our previous results, we focus on the effect of loans. One important concern is that our fixed-effect regressions, while controlling for fixed firm-level unobservables and time-varying industry-level unobservables, do not guarantee that appropriate comparison groups are handled satisfactorily in the analysis. One way to overcome this limitation is to use matching techniques to more effectively compare similar firms with varying levels of BNDES loans.

In particular, we adopt the bias-corrected matching estimator proposed by Abadie and Imbens (2011) and Abadie, Drukker, Herr, and Imbens (2004). Because we have few cases of firms without BNDES loans over an extended period, we identify cases of transition in which firms increased the extent of their loans, compared to similar firms for which such an increase was not observed. To guarantee comparability, we consider firms that had already borrowed from BNDES in the pre-treatment period. For any given year, $t$, pre-treatment outcomes and matching (observable) variables are computed as averages in the period between $t-3$ and $t-1$, whereas posttreatment measures are computed as averages in the period between $t+1$ and $t+3$. Treated observations involve cases in which there was a given increase in the ratio of BNDES loans to total debt, computed as the difference between the average percentage of loans in the post- and pretreatment periods. ${ }^{10}$ Based on those measured differences, we consider three distinct cutoff levels to classify firms in the treatment condition: 5,10 , and 15 percentage points. That is, when the 10percentage-point cutoff level is used, we identify treated cases for which the ratio of BNDES loans to total debt increased by 10 percentage points in the post-treatment period. 
We also compute the outcome variables as differences between the post- and pre-treatment periods to control for fixed unobservable firm-level effects. Our result of interest is then the differences-in-differences average treatment effect for the treated (ATT); that is, variations in a given outcome (performance or investment) for the treated cases as compared to similar control firms for which a corresponding increase in loans was not observed. We allow one matched observation per treated firm, imposing exact matching for year $(t)$ and industry classification. ${ }^{11}$ Other matching variables include our set of control variables: leverage, size (assets), and dummies coding type of ownership and whether the firm belongs to a group. Previous research has also indicated that matching is improved if we use pre-treatment outcome variables in the matching procedure (Cook, Shadish, \& Wong, 2008). For instance, in the estimation of the ATT considering variations in ROA, we also include as a matching variable the pre-treatment ROA.

The results, shown in Table 7, appear to confirm our previous findings: The only consistent effect of having BNDES loans is on Finex/Debt, especially for variations in loans larger than 10 percentage points. Loans apparently do not consistently change performance and investment outcomes, except for a reduction in the cost of capital.

[Table 7 around here]

\subsection{Another robustness check: Analysis of financial constraints}

Following Fazzari, Hubbard, and Petersen (1988), we examine if development bank loans change the financing constraints of Brazilian firms. (for an application to state-owned banks, see Behr, Norden, \& North, 2012). The basic idea of the model is that the investment ratios (capital expenditures to fixed assets) of financially constrained firms are more sensitive to an increase or decrease in cash flow. That is, an increase in cash flow should have a larger positive impact on investment. Following that literature, we measure investment as the ratio of yearly capital expenditures to the initial stock of fixed capital (observed at the end of the previous year). We also 
use the ratio of net profits to the initial stock of fixed capital as a proxy for cash flow and Tobin's q as a measure of investment opportunity. According to this perspective, if BNDES's allocations reduce capital constraints, then an increase in those allocations should reduce the marginal impact of cash flow on investment. We test this hypothesis by interacting the BNDES variables with the proxy for cash flow, then observing whether or not the coefficient of this interaction is significantly negative (see Behr et al., 2012). In our regressions, we control for leverage, group membership, foreign ownership, and firm, year, and industry-year fixed effects.

The results, shown in Table 8, do indicate that an increase in cash flow positively affects the investment ratio. However, the BNDES variables do not significantly affect investments, either directly or indirectly through the interaction with cash flow. Therefore, at least in our sample, there is again lack of support for the hypothesis that development banks reduce credit constraints and promote investment. $^{12}$

[Table 8 around here]

\subsection{Selection process: Impact of firm-level variables on BNDES allocations}

We now examine the selection process by considering BNDES loan and equity allocations as dependent variables. Tables 9 and 10 present regression results for BNDES loans and equity, respectively. Let us first analyze how the firm-level performance variables (ROA, EBITDA/Assets and Tobin's q) affect BNDES loans and equity. To capture temporal effects, we add lagged values of the performance variables (for example, BNDES may take into consideration firms' past performance). We find some positive effects of ROA and EBITDA/Assets in some specifications (Columns 1, 6, and 7 of Table 9), but the level of significance is marginal $(p<0.10)$. We also fail to detect any significant effect of Tobin's q. As for BNDES's decisions to acquire equity, these investments do not appear to be affected by our performance variables in any meaningful way (Table 10). Although we do not find strong consistent effects of the performance variables, neither 
do our data support the soft-budget constraint hypothesis (of the political view) that BNDES is systematically bailing out poorly performing firms. If anything, BNDES loans are not generally targeting bad projects.

[Tables 9 and 10 around here]

We also find that political variables matter as determinants of loans (Table 9), although no consistent effects are found in terms of equity (Table 10). Stronger effects are found in the case of donations for deputies. In general, an increase in the number of donations for deputies who win elections increases the extent of loans received from BNDES, especially for the margins of victory involving 10 and 25 thousand votes $(p<0.05)$. We also find that donations for defeated deputy candidates decrease the size of total loans, although less consistent effects are found when loans are taken as a percentage of total debt. A possible explanation for the negative effect detected in the case of losing candidates is that betting on a candidate who eventually wins while simultaneously betting on a candidate that loses the election may represent lower concentrated effort (and money) for the candidate who eventually wins, assuming that firms have limited capital for donations. ${ }^{13}$ The effect of donations also remains significant when we add in the same regression financial performance variables, such as ROA and EBITDA.

With respect to the choice of equity, we detect no consistent effects (see Table 10). Donations to losing candidates for positions subject to majority rule (president, senator, and state governor) appear to reduce BNDES equity for higher margins of victory but not in the case of more competitive elections. We also performed additional analyses restricting the analysis to the subsample of firms that donated to candidates who either lost or won by a small margin. As it turns out, the overall conclusion does not change much (results not reported here, but available upon request). ${ }^{14}$ 
To assess the magnitude of the effect of donations on loans, consider the estimate for the intermediate margin of victory of 25 thousand votes (Column 8 of Table 9). Because the effect of winning candidates on BNDES loans is simply the estimated coefficient of winning candidates times the size of BNDES loans (US\$ 166 million, on average), we find that an additional donation for a winning deputy apparently increases loans by around US\$ 45.9 million. Considering our previous results that BNDES loans reduce financial expenses somewhere between $4 \%$ and $12 \%$, the private gain from each additional donation to a winner would bring net yearly benefits of between US\$ 1.8 and 5.5 million until the next election. In contrast, the average donation per winning candidate for each firm in our database was US\$22,820 in 2002 and US\$ 43,903 in 2006. Even if we consider that there may be substantial donations "under the table" — estimated by Araujo (2004) as twice or ten times the official figures - the magnitude of the estimated effect is far from trivial. In addition, by establishing political ties, firms may receive benefits beyond loans.

This finding should not necessarily be interpreted as an outright crony relation between BNDES bureaucrats and capitalists. BNDES is well known for having a competent technical staff that scrutinizes a potential borrower's repayment capability (Evans, 1995; Schneider, 1991). A likely explanation is that firms donating to winners are more likely to be engaged in preferential transactions with the government (Arvate et al., 2013; Boas et al., 2014), which tend to be heavily funded with state capital. In this sense, the more consistent effects detected for deputies is not surprising. Given the competitive nature of elections for the Chamber of Deputies, Samuels (2002) argues, politicians have incentives to "trade pork for money, in the form of campaign contributions" (p. 846). In other words, winning candidates will be in the position to convince the government to approve pork-barrel projects favoring firms that funded their campaigns. Those winning candidates can also appoint allies in the management ranks of state-controlled firms controlling the selection of large projects. Such projects include concessions, government-sponsored projects, and other types 
of public contract, all of which have been accompanied by substantial BNDES funding (Lazzarini, 2011).

Collectively, our results provide stronger support for the rent-seeking hypothesis (of the political view) than for the industrial policy view. The evidence supporting the rent-seeking hypothesis shows that campaign donations appear to influence BNDES allocations, although apparently this effect does not cause bad firms to be systematically selected. BNDES is not generally picking bad projects with negative implications for its own financial health; that is, we find no evidence to support the soft-budget constraint hypothesis. A likely reason is that politically connected firms in our database do not appear to be systematic underperformers. These firms want cheaper credit but they are not bankrupt firms in need of a financial lifeline. Even good firms have incentives to be politically connected as a way to guarantee subsidized loans.

This is not to say, however, that bailouts never occur. In 2011, for instance, BNDES helped rescue Brazilian meatpacker JBS-Friboi, which aggressively expanded internationally by acquiring Swift and Pilgrim's Pride, among other firms. The expansion was accomplished at the cost of a substantial debt, so in 2011, JBS and BNDES agreed to reconvert part of the BNDES loans into shares. ${ }^{15}$ Yet, although such cases are important, our findings indicate that they are not the norm, at least in the period covered by our database.

\section{Concluding Remarks}

Our study contributes to the evolving debate on the role of state-owned development banks and state-led intervention in credit markets. Our in-depth analysis of Brazil's BNDES, one of the largest development banks in the world, reveals a more nuanced picture of development banks. On the one hand, BNDES does not appear to be systematically picking or bailing out failing firms and its operations are, to some extent, profitable. Thus, our results fail to detect the type of distortion proposed by the political view - that is, that development banks target firms with bad performance. On the other hand, BNDES's loans and equity allocations do not appear to have a consistent effect 
on the performance and investment decisions of the firms in our sample, other than a reduction in financial expenses due to the effect of governmental subsidies. We also see that politically connected firms seem to have an advantage in obtaining BNDES loans. Yet this mechanism does not seem to be self-selecting poor performers only. All firms, with good or bad projects, have incentives to attract BNDES funding as a way to reduce their financial costs, even firms whose projects could be funded with other sources of capital. Therefore, although our results are inconsistent with the industrial policy literature, which sees development banks as mechanisms to unlock productive investments through state-led credit, they do not completely support the opposing perspective of development banks as tools to help and rescue failed industrialists.

Therefore, our study suggests a different form of credit misallocation associated with stateowned banks. Much of the extant literature emphasizes that those banks tend to target bad firms that use their political connections to access subsidized credit and other types of support. While confirming that political connections matter, our study instead shows that loans are not systematically being channeled to underperformers. In our context, the most apparent problem is that BNDES is lending to firms that are not changing their performance and investment conditional on the new loans, probably because they could fund their projects with other sources of capital. Even these firms will have incentives to get BNDES loans and to profit from the associated subsidies. By targeting those firms, development banks may also leave only high-risk firms to private lenders, therefore inhibiting the emergence of a private market for long-term lending (e.g. Antunes et al., 2012; Cull et al., 2013). On the other hand, as mentioned before, lending to low-risk borrowers reduces the incidence of nonperforming loans. Thus, according to criteria set by financial regulatory agencies in Brazil, by 2013 the percentage of credit disbursed by BNDES considered with medium to high risk was only $0.3 \%$, compared to $8.2 \%$ and $5.2 \%$ in the case of private and other state-owned banks respectively (BNDES, 2013). In addition, we cannot rule out the possibility that borrowers are investing in projects with other types of externality. Thus, a more 
complete analysis of the welfare effects of development banks would need to consider a broad range of positive effects beyond firm-level performance and investment.

Our focus on a single bank also calls for more studies more studies on a broader range of countries that have distinct institutional characteristics, are at various stages of development, and are using other strategies to mitigate credit constraints. Some governments, for instance, may create an institutional framework with improved monitoring and assessment of the activity of development banks. Firm-level performance effects should increase when loans and equity allocations are subject to clear targets dictating not only which firms should receive state capital but also under which conditions development banks should cease their support. Indeed, performancecontingent support is a key aspect emphasized by the industrial policy literature (e.g. Amsden, 1989). Development banks may also target firms with heavier financial constraints and work handin-hand with private banks. In Chile, for instance, state-owned Production Development Corporation (CORFO) is focused on financially constrained small and medium enterprises and only acts by guaranteeing part of the debt provided by private financial intermediaries. In this case, we should not expect the type of misallocation suggested in our paper because the state is not channeling resources to firms that could raise capital from other sources. The diversity of strategies used by development financial institutions has so far not been satisfactorily examined and certainly calls for future empirical work assessing the conditions under which development banks can more effectively spur productive investments.

\section{References}

Abadie, A., Drukker, D., Herr, J. L., \& Imbens, G. (2004). Implementing matching estimators for average treatment effects in Stata. Stata Journal, 4(3), 290-311.

Abadie, A., \& Imbens, G. (2011). Bias-corrected matching estimators for average treatment effects. Journal of Business \& Economic Statistics, 29(1), 1-11. 
Ades, A., \& Di Tella, R. (1997). National champions and corruption: some unpleasant interventionist arithmetic. The Economic Journal, 107(443), 1023-1042.

Almeida, M. (2009). Desafios da real política industrial brasileira no século XXI. Texto para discussão 1452, IPEA.

Amsden, A. H. (1989). Asia's next giant: South Korea and late industrialization. New York: Oxford University Press.

Amsden, A. H. (2001). The rise of 'the rest': challenges to the West from late-industrializing economies. Oxford: Oxford University Press.

Antunes, A., Cavalcanti, T., \& Villamil, A. (2012). The effects of credit subsidies on development.Unpublished manuscript.

Araújo, C. E. P. d. (2004). Financiamento de campanhas eleitorais. Revista de Informação Legislativa, 41, 59-66.

Armendáriz de Aghion, B. (1999). Development banking. Journal of Development Economics, 58, 83-100.

Aronovich, S., \& Fernandes, A. G. (2006). A atuação do governo no mercado de capitais: experiências de IFDs em países desenvolvidos. Revista do BNDES, 13(25), 3-34.

Arvate, P., Barbosa, K. d. S., \& Fuzitani, E. (2013). Campaign donation and government contracts in Brazilian states, " T Unpublished manuscript.

Bailey, W., Huang, W., \& Yang, Z. (2011). Bank loans with Chinese characteristics: some evidence on inside debt in a state-controlled banking system. Journal of Financial and Quantitative Analysis, 46(6), 1795-1830.

Bandeira-de-Mello, R., \& Marcon, R. (2005). Unpacking firm effects: modeling political alliances in variance decomposition of firm performance in turbulent environments. Brazilian Administration Review, 2(1), 21-37. 
Behr, P., Norden, L., \& North, F. (2012). Financial contraints of private firms and bank lending behavior.Unpublished manuscript.

BNDES. (2002). 50 Anos: Histórias Setoriais. São Paulo: DBA Artes Gráficas.

BNDES. (2013). Relatório de administração - sistema BNDES.Unpublished manuscript, Rio de Janeiro.

Boas, T., Hidalgo, F. D., \& Richardson, N. (2014). The spoils of victory: campaign donations and government contracts in Brazil. The Journal of Politics, 76(2), 415-429.

Bruck, N. (1998). The role of development banks in the Twenty-First Century. Journal of Emerging Markets, 3, 39-67.

Cameron, R. (1961). France and the economic development of Europe, 1800-1914. Princeton: Princeton University Press.

Campos, R. d. O. (1969). A Retrospect Over Brazilian Development Plans. In H. S. Ellis (Ed.), The Economy of Brazil (pp. 317-344). Berkeley and Los Angeles: University of California Press.

Carvalho, D. (2010). The real effects of government-owned banks: evidence from an emerging market.Unpublished manuscript.

Caughey, D., \& Sekhon, J. (2011). Elections and the regression discontinuity design: lessons from close US house races, 1942-2008. Political Analysis, 19(4), 385-408.

Claessens, S., Feijen, E., \& Laeven, L. (2008). Political connections and preferential access to finance: the role of campaign contributions. Journal of Financial Economics, 88, 554-580.

Coelho, D., \& De Negri, J. A. (2010). Impacto do financiamento do BNDES sobre a produtividade das empresas: uma aplicação do efeito quantílico de tratamento.Unpublished manuscript.

Cole, S. (2009). Fixing Market Failure or Fixing Elections? Agricultural Credit in India. American Economic Journal: Applied Economics, 1(1), 219-250. 
Colombo, M. G., Giannangeli, S., \& Grilli, L. (Forthcoming). Public subsidies and the employment growth of high-tech startups: assessing the impact of selective and automatic support schemes. Industrial and Corporate Change.

Cook, T. D., Shadish, W. R., \& Wong, V. C. (2008). Three conditions under which experiments and observational studies produce comparable causal estimates: new findings from withinstudy comparisons. Journal of Policy Analysis and Management, 27(4), 724-750.

Cull, R. J., Li, W., Sun, B., \& Xu, L. C. (2013). Government Connections and Financial Constraints: Evidence from a Large Representative Sample of Chinese Firms. World Bank Working Paper 6352.

Curralero, C. R. B. (1998). A atuação do sistema BNDES como instituição financeira de fomento no periodo 1952-1996. Universidade Estadual de Campinas, Campinas.

De Negri, J. A., Maffioli, A., Rodriguez, C. M., \& Vázquez, G. (2011). The impact of public credit programs on Brazilian firms.Unpublished manuscript.

Dinç, I. S. (2005). Politicians and banks: Political influences on government-owned banks in emerging markets. Journal of Financial Economics, 77, 453-479.

Evans, P. (1995). Embedded autonomy: states and industrial transformation. Princeton: Princeton University Press.

Faccio, M. (2006). Politically connected firms. American Economic Review, 96(1), 369-386.

Falck, O., Gollier, C., \& Woessmann, L. (2011). Arguments for and against policies to promote national champions. In O. Falck, C. Gollier \& L. Woessmann (Eds.), Industrial policy for national champions (pp. 3-9). Cambridge: MIT Press.

Fazzari, S. M., Hubbard, R. G., \& Petersen, B. C. (1988). Financing constraints and corporate investment. Brookings Papers on Economic Activity, 1, 141-195.

Ferraz, J. C., Além, A. C., \& Madeira, R. F. (2013). A contribuição dos bancos de desenvolvimento para o financiamento de longo prazo. Revista do BNDES, 40, 5-42. 
Fordwor, K. D. (1981). Some unresolved problems of the African Development Bank. World Development, 9(11-12), 1129-1139.

Gerschenkron, A. (1962). Economic backwardness in historical perspective. Cambridge: Harvard University Press.

Haber, S. (2002). Introduction: the political economy of crony capitalism. In S. Haber (Ed.), Crony capitalism and economic growth in Latin America: theory and evidence (pp. xi-xxi). Stanford: Hoover Institution Press.

Hainz, C., \& Hakenes, H. (2008). The politician and the banker.Unpublished manuscript.

Inoue, C. F. K. V., Lazzarini, S. G., \& Musacchio, A. (2013). Leviathan as a minority shareholder: firm-level performance implications of equity purchases by the government Academy of Management Journal, 56(6), 1775-1801.

Inoue, C. F. V. (2011). Capitalismo de Estado no Brasil: uma análise das participações minoritárias do Banco Nacional de Desenvolvimento Econômico e Social (BNDES) entre 1995 e 2009.Unpublished manuscript.

Khanna, T., \& Yafeh, Y. (2007). Business groups in emerging markets: paragons or parasites? Journal of Economic Literature, 45, 331-372.

Khwaja, A. I., \& Mian, A. (2005). Do lenders favor politically connected firms? Rent provision in an emerging financial market. Quarterly Journal of Economics, 120(4), 1371-1411.

Kornai, J. (1979). Resource-constrained versus demand-constrained systems. Econometrica, 47(4), 801-819.

Krueger, A. O. (1990). Government failures in development. Journal of Economic Perspectives, 4(3), 9-23.

La Porta, R., Lopez de Silanes, F., \& Shleifer, A. (2002). Ownership of banks. Journal of Finance, 57(1), 265-302. 
Lamenza, G., Pinheiro, F. P., \& Giambiagi, F. (2011). A capacidade de desembolso do BNDES durante a década de 2010. Revista do BNDES, 36, 43-88.

Lazzarini, S. G. (2011). Capitalismo de laços: os donos do Brasil e suas conexões. Rio de Janeiro: Campus/Elsevier.

Leff, N. H. (1968). Economic policy-making and development in Brazil, 1947-1964. New York: John Wiley \& Sons.

Lin, J., \& Chang, H.-J. (2009). Should industrial policy in developing countries conform to comparative advantage or defy it? A debate between Justin Lin and Ha-Joon Chang. Development Policy Review, 27(5), 483-502.

Musacchio, A. (2009). Experiments in financial democracy: corporate governance and financial development in Brazil, 1882-1950. Cambridge: Cambridge University Press.

Musacchio, A., \& Lazzarini, S. G. (2014). Reinventing State Capitalism: Leviathan in Business, Brazil and Beyond. Cambridge: Harvard University Press.

Najberg, S. (1989). Privatização de Recursos Públicos: Os Empréstimos do Sistema BNDES ao Setor Privado Nacional com Correção Monetária Parcial. PUC-RIO, Rio de Janeiro.

Ndongko, W. A. (1975). Development bank lending: The Cameroon experience. World Development, 3(6), 421-425.

Nelson, P. J. (2001). Transparency mechanisms at the multilateral development banks. World Development, 29(11), 1835-1847.

Nunes, E. d. O. (1997). A grámatica política do Brasil: clientelismo e insulamento burocrático. Sao Paulo: J. Zahar Editor.

Ottaviano, G. I. P., \& Sousa, F. L. (2007). The effect of BNDES loans on the productivity of Brazilian manufacturing firms.Unpublished manuscript. 
Pereira, T. R., Simões, A., \& Carvalhal, A. (2011). Mensurando o resultado fiscal das operações de empréstimo do Tesouro ao BNDES: custo ou ganho líquido esperado para a União?Unpublished manuscript, Rio de Janeiro.

Rajan, R. G., \& Zingales, L. (1996). Financial dependence and growth. The American Economic Review, 88(3), 559-586.

Rodrik, D. (1995). Getting interventions right: how South Korea and Taiwan grew rich. Economic Policy, 20, 55-107.

Rodrik, D. (2004). Industrial policy for the twenty-first century. CEPR Discussion Paper 4767, London.

Samuels, D. (2002). Pork barreling is not credit claiming or advertising: campaign finance and the sources of personal vote in Brazil. The Journal of Politics, 64(3), 846-863.

Sapienza, P. (2004). The effects of government ownership on bank lending. Journal of Financial Economics, 72(2), 357-384.

Schneider, B. R. (1991). Politics within the state: elite bureaucrats and industrial policy in authoritarian Brazil. Pittsburgh: University of Pittsburgh Press.

Schneider, B. R. (2004). Business politics and the State in twentieth-century Latin America. Cambridge: Cambridge University Press.

Sousa, F. L. (2010). Custos, BNDES e produtividade.Unpublished manuscript.

Tendler, J. (1968). Electric Power in Brazil. Cambrdige, Ma.: Harvard University Press.

Villela, A. (1995). Taxa de Investimento e Desempenho do BNDES: 1985/94. Revista do BNDES, 2(4), 129-142.

Yeyati, E. L., Micco, A., \& Panizza, U. (2004). Should the government be in the banking business? The role of state-owned and development banks.Unpublished manuscript. 


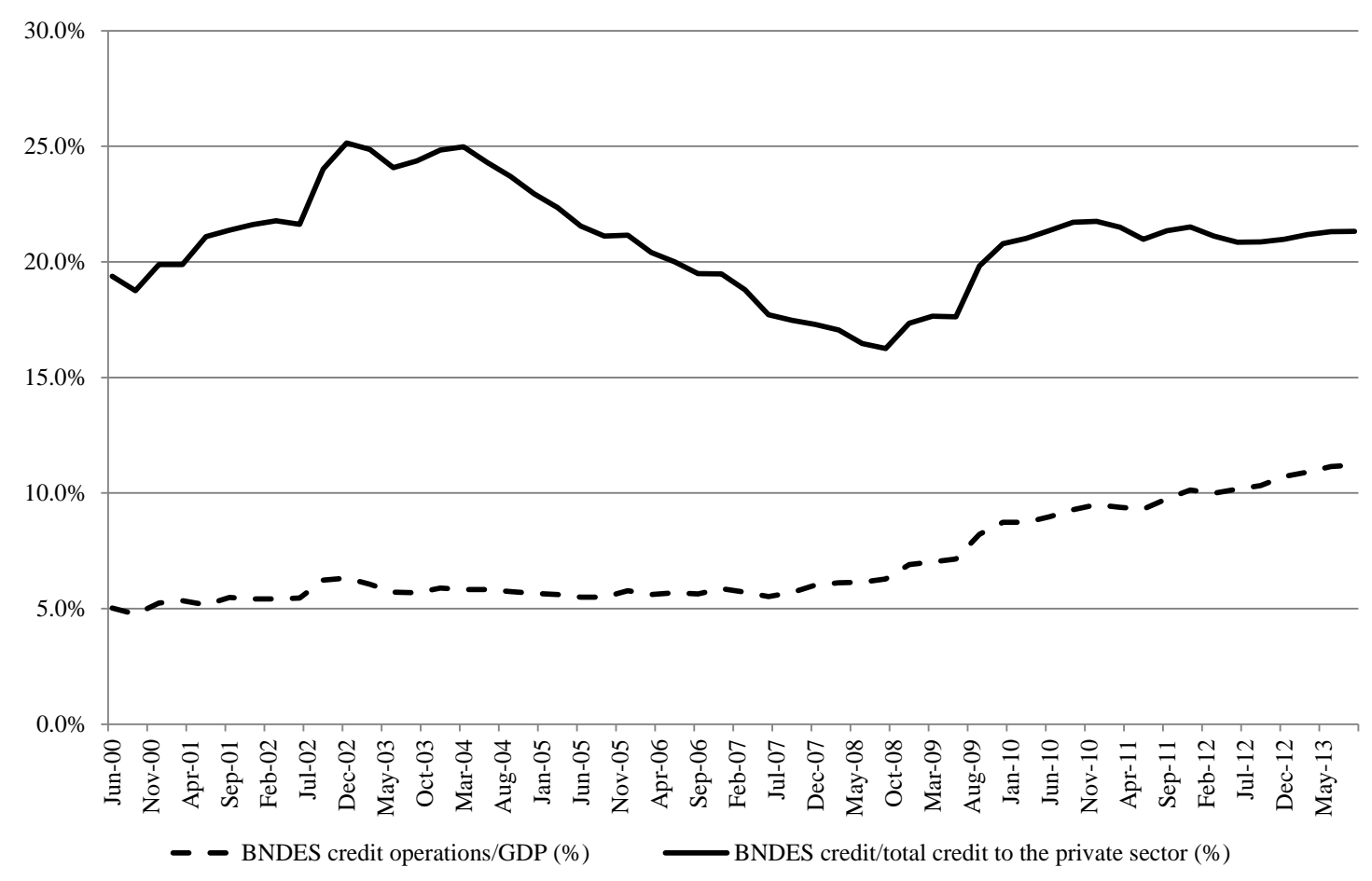

Figure 1

BNDES: Evolution of credit

Source: Central Bank of Brazil

Table 1

BNDES's participation in the firms included in the database

\begin{tabular}{c|c|ccc|ccc}
\hline & & \multicolumn{2}{|c|}{ Firms observed with BNDES loans } & \multicolumn{2}{c}{ Firms observed with BNDES equity } \\
\cline { 3 - 7 } Year & $\begin{array}{c}\text { Firms in } \\
\text { sample }\end{array}$ & $\begin{array}{c}\text { Number of } \\
\text { firms }\end{array}$ & $\begin{array}{c}\% \text { of } \\
\text { sample }\end{array}$ & $\begin{array}{c}\text { BNDES loans } \\
\text { to total debt, } \\
\text { average (\%) }\end{array}$ & $\begin{array}{c}\text { Number } \\
\text { of firms }\end{array}$ & $\begin{array}{c}\% \text { of } \\
\text { sample }\end{array}$ & $\begin{array}{c}\text { BNDES } \\
\text { equity share, } \\
\text { average (\%) }\end{array}$ \\
\hline 2002 & 218 & 115 & 52.8 & 25.2 & 13 & 6.0 & 17.0 \\
2003 & 196 & 109 & 55.6 & 30.1 & 12 & 6.1 & 17.6 \\
2004 & 179 & 102 & 57.0 & 31.7 & 12 & 6.7 & 14.4 \\
2005 & 170 & 96 & 56.5 & 31.1 & 17 & 10.0 & 15.4 \\
2006 & 176 & 95 & 54.0 & 31.4 & 20 & 11.4 & 13.0 \\
2007 & 203 & 114 & 56.2 & 31.8 & 25 & 12.3 & 12.3 \\
2008 & 208 & 128 & 61.5 & 28.7 & 28 & 13.5 & 13.3 \\
2009 & 215 & 128 & 59.5 & 32.9 & 31 & 14.4 & 13.2 \\
\hline Median & & \multicolumn{7}{c}{5} & 56.3 & 31.2 & & 10.7 & 13.9 \\
\hline
\end{tabular}


Table 2

Summary statistics and description of variables

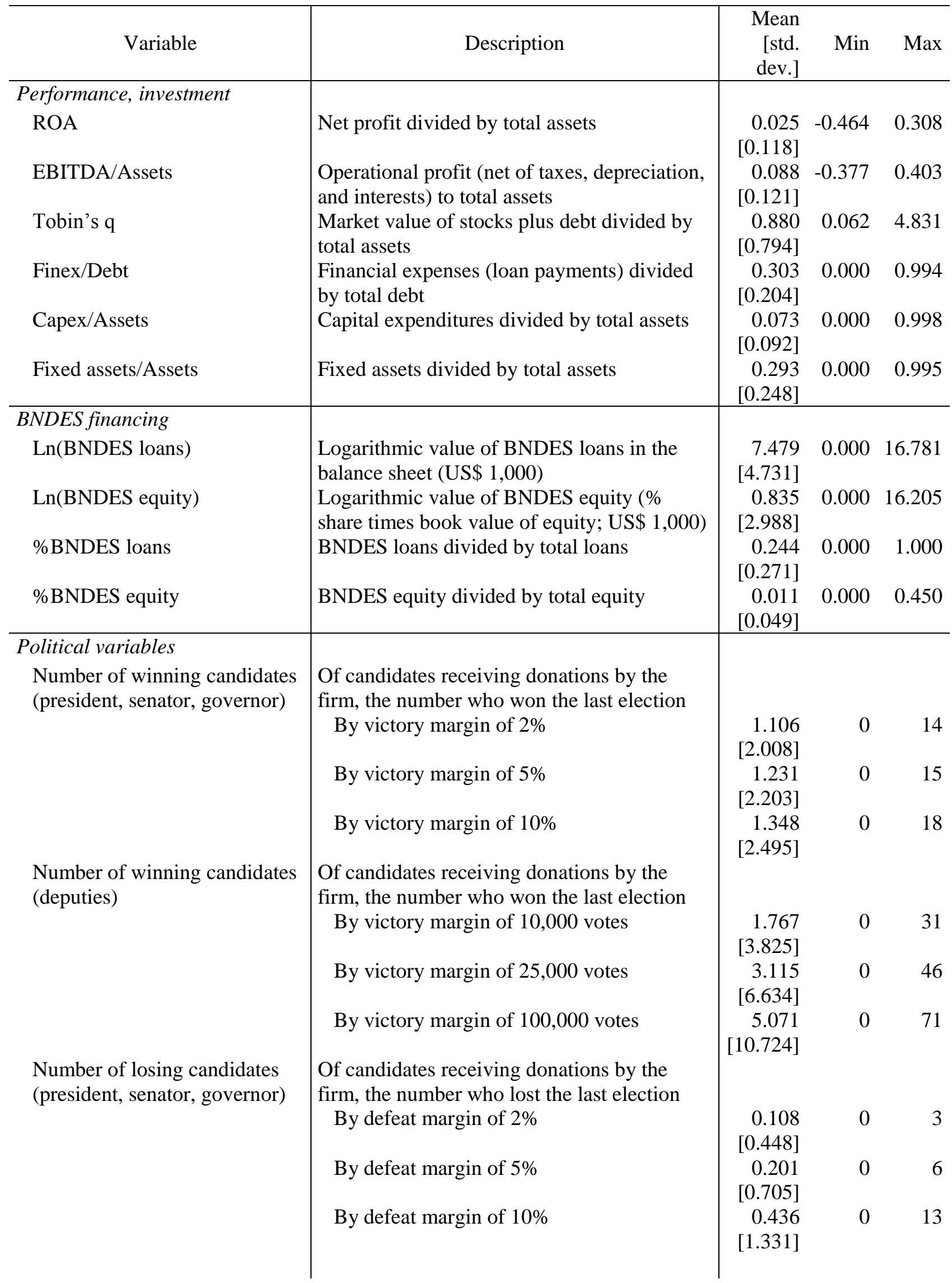




\begin{tabular}{|c|c|c|c|c|}
\hline $\begin{array}{l}\text { Number of losing candidates } \\
\text { (deputies) }\end{array}$ & $\begin{array}{l}\text { Of candidates receiving donations by the } \\
\text { firm, the number who lost the last election } \\
\text { By defeat margin of } 10,000 \text { votes } \\
\text { By defeat margin of } 25,000 \text { votes } \\
\text { By defeat margin of } 100,000 \text { votes }\end{array}$ & $\begin{array}{r}1.205 \\
{[3.075]} \\
2.510 \\
{[5.803]} \\
3.963 \\
{[9.076]}\end{array}$ & 0 & 56 \\
\hline \multicolumn{5}{|l|}{ Controls } \\
\hline Belongs to a group & $\begin{array}{l}\text { Dummy variable coded } 1 \text { if the firm belongs } \\
\text { to a business group }\end{array}$ & $\begin{array}{r}0.473 \\
{[0.499]}\end{array}$ & 0 & \\
\hline Ln(Assets) & Logarithmic value of total assets (US\$1,000) & $\begin{array}{r}12.636 \\
{[1.686]}\end{array}$ & 1.386 & 19.015 \\
\hline Leverage & Total debt divided by total assets & $\begin{array}{r}0.186 \\
{[0.174]}\end{array}$ & 0.000 & 0.957 \\
\hline Foreign & $\begin{array}{l}\text { Dummy variable coded } 1 \text { if the firm is } \\
\text { foreign-controlled }\end{array}$ & $\begin{array}{r}0.200 \\
{[0.400]}\end{array}$ & 0 & \\
\hline
\end{tabular}


Table 3

Summary of hypothesized effects

\begin{tabular}{|l|c|c|}
\cline { 2 - 3 } \multicolumn{1}{c|}{} & Industrial policy view & Political view \\
\hline $\begin{array}{l}\text { Effect of BNDES on firm- } \\
\text { level performance } \\
\text { Tobin's q, Finex/Debt) }\end{array}$ & $\begin{array}{c}\text { Positive (including, but not } \\
\text { only, through a reduction in } \\
\text { financial expenses). }\end{array}$ & $\begin{array}{c}\text { If any, only through a } \\
\text { reduction in financial } \\
\text { expenses due to subsidies. }\end{array}$ \\
\hline $\begin{array}{l}\text { Effect of BNDES on } \\
\text { investments } \\
\text { (Capex/Assets, } \\
\text { Investment/Assets) }\end{array}$ & Positive. & Null. \\
\hline $\begin{array}{l}\text { Determinants of selection: } \\
\text { factors affecting BNDES } \\
\text { allocations (loans, equity) }\end{array}$ & $\begin{array}{c}\text { No particular effect; BNDES } \\
\text { may revamp firms with good } \\
\text { performance or select good } \\
\text { firms to guarantee repayment. } \\
\text { Alternatively, BNDES may not } \\
\text { take into consideration past } \\
\text { performance if the bank wants } \\
\text { to stimulate firms with latent } \\
\text { advantages. }\end{array}$ & $\begin{array}{c}\text { Effect of firm-level } \\
\text { nerformance on selection: } \\
\text { negative (bailing out failing } \\
\text { firms). } \\
\text { Effect of political } \\
\text { connections: positive. }\end{array}$ \\
\hline \multicolumn{2}{|c}{} \\
\hline
\end{tabular}

Table 4

Mean comparison tests

\begin{tabular}{|c|c|c|c|c|}
\hline \multirow[t]{2}{*}{ Variable } & \multicolumn{2}{|c|}{$\begin{array}{c}\text { Firm was observed with BNDES } \\
\text { loans? }\end{array}$} & \multicolumn{2}{|c|}{$\begin{array}{c}\text { Firm was observed with BNDES } \\
\text { equity? }\end{array}$} \\
\hline & No & Yes & No & Yes \\
\hline \multirow{4}{*}{ ROA } & 0.039 & $0.056^{*}$ & 0.049 & 0.041 \\
\hline & [0.008] & [0.003] & [0.003] & [0.009] \\
\hline & $N=290$ & $N=887$ & $N=1405$ & $N=158$ \\
\hline & 0.075 & $0.123 * * *$ & 0.112 & $0.091 *$ \\
\hline \multirow[t]{3}{*}{ EBITDA/Assets } & [0.009] & [0.004] & [0.003] & {$[0.010]$} \\
\hline & $N=279$ & $N=861$ & $N=1349$ & $N=157$ \\
\hline & 1.199 & 1.147 & 1.169 & 1.159 \\
\hline \multirow[t]{3}{*}{ Tobin's q } & [0.071] & [0.032] & [0.028] & [0.063] \\
\hline & $N=239$ & $N=760$ & $N=1166$ & $N=154$ \\
\hline & 0.328 & $0.265^{* * *}$ & 0.289 & $0.255 \dagger$ \\
\hline \multirow[t]{3}{*}{ Finex/Debt } & {$[0.020]$} & [0.007] & {$[0.006]$} & {$[0.017]$} \\
\hline & $N=129$ & $N=689$ & $N=933$ & $N=112$ \\
\hline & 0.069 & 0.078 & 0.073 & 0.076 \\
\hline \multirow[t]{3}{*}{ Capex/Assets } & [0.008] & [0.003] & [0.003] & [0.008] \\
\hline & $N=273$ & $N=852$ & $N=1333$ & $N=153$ \\
\hline & 0.157 & $0.266^{* * *}$ & 0.243 & $0.206^{*}$ \\
\hline \multirow[t]{3}{*}{ Fixed assets/Assets } & [0.013] & [0.008] & [0.006] & [0.019] \\
\hline & $N=290$ & $N=887$ & $N=1407$ & $N=158$ \\
\hline & 12.287 & $13.119 * * *$ & 12.621 & $14.093 * * *$ \\
\hline \multirow[t]{2}{*}{ Ln(Assets) } & [0.107] & [0.053] & [0.044] & [0.167] \\
\hline & $N=290$ & $N=887$ & $N=1407$ & $N=158$ \\
\hline
\end{tabular}


Table 5

Effect of BNDES loans and equity on firm-level performance variables: Fixed-effect regressions

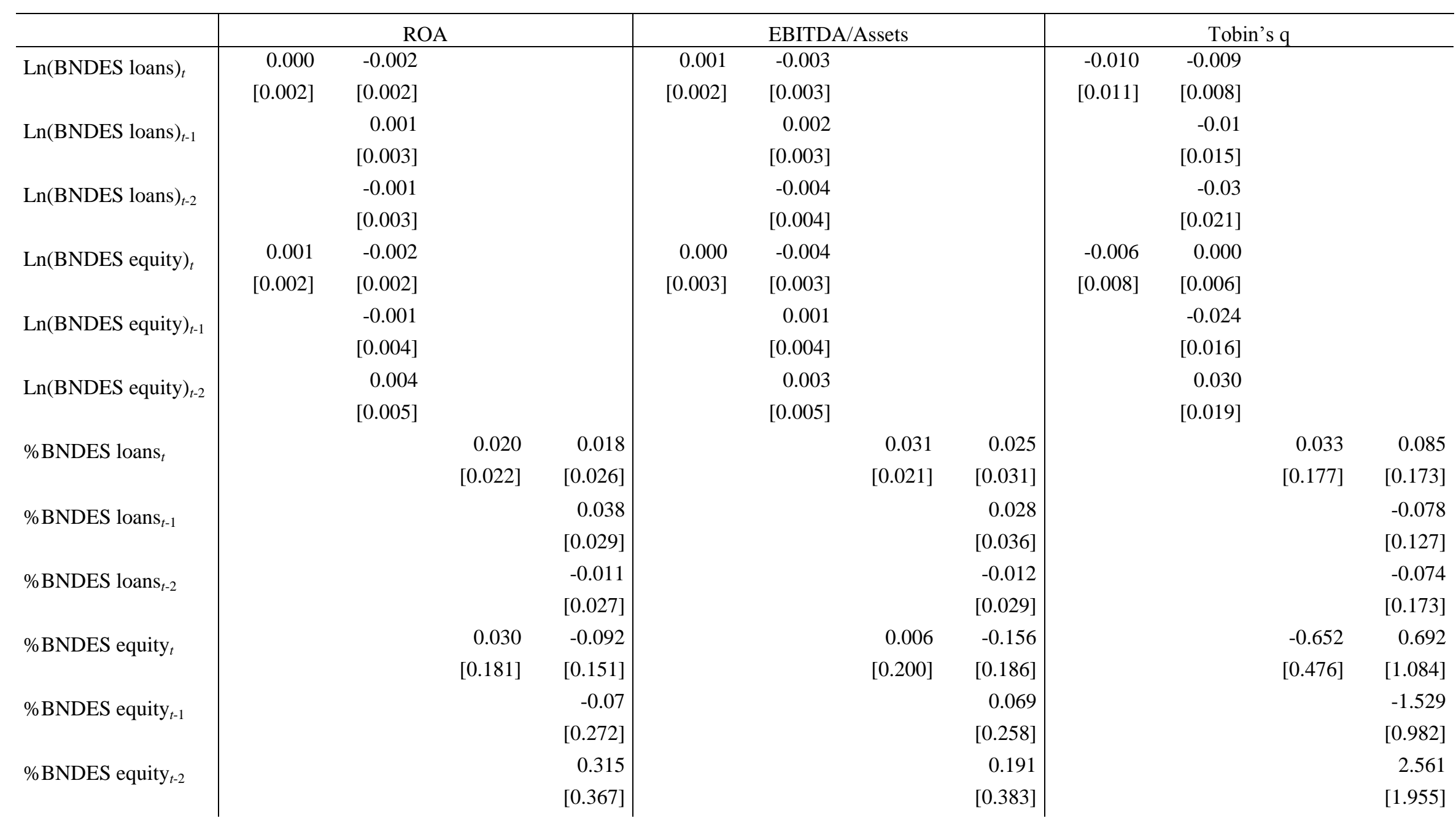




\begin{tabular}{|c|c|c|c|c|c|c|c|c|c|c|c|c|}
\hline Belongs to a group & $\begin{array}{r}0.018 \\
{[0.057]}\end{array}$ & $\begin{array}{r}-0.145 * * * \\
{[0.033]}\end{array}$ & $\begin{array}{r}0.016 \\
{[0.058]}\end{array}$ & $\begin{array}{r}-0.137 * * * \\
{[0.035]}\end{array}$ & $\begin{array}{r}-0.012 \\
{[0.051]}\end{array}$ & $\begin{array}{r}-0.161 * * * \\
{[0.031]}\end{array}$ & $\begin{array}{r}-0.011 \\
{[0.052]}\end{array}$ & $\begin{array}{r}-0.148 * * * \\
{[0.039]}\end{array}$ & $\begin{array}{r}-0.118 \\
{[0.178]}\end{array}$ & $\begin{array}{r}0.010 \\
{[0.159]}\end{array}$ & $\begin{array}{r}-0.114 \\
{[0.171]}\end{array}$ & $\begin{array}{r}0.119 \\
{[0.137]}\end{array}$ \\
\hline Ln(Assets) & $\begin{array}{r}0.072 * * \\
{[0.022]}\end{array}$ & $\begin{array}{c}0.103 * \\
{[0.042]}\end{array}$ & $\begin{array}{r}0.079 * * \\
{[0.029]}\end{array}$ & $\begin{array}{c}0.113 * \\
{[0.044]}\end{array}$ & $\begin{array}{c}0.062 * \\
{[0.026]}\end{array}$ & $\begin{array}{r}0.081 * \\
{[0.040]}\end{array}$ & $\begin{array}{c}0.082 * \\
{[0.032]}\end{array}$ & $\begin{array}{c}0.090 * \\
{[0.040]}\end{array}$ & $\begin{array}{r}-0.076 \\
{[0.202]}\end{array}$ & $\begin{array}{r}-0.009 \\
{[0.262]}\end{array}$ & $\begin{array}{r}-0.046 \\
{[0.207]}\end{array}$ & $\begin{array}{r}0.145 \\
{[0.258]}\end{array}$ \\
\hline Leverage & $\begin{array}{r}-0.223 * * * \\
{[0.047]}\end{array}$ & $\begin{array}{r}-0.236 * * * \\
{[0.055]}\end{array}$ & $\begin{array}{r}-0.212 * * * \\
{[0.050]}\end{array}$ & $\begin{array}{r}-0.228 * * * \\
{[0.055]}\end{array}$ & $\begin{array}{r}-0.154 * * \\
{[0.050]}\end{array}$ & $\begin{array}{r}-0.148 * * \\
{[0.051]}\end{array}$ & $\begin{array}{c}-0.137 * \\
{[0.053]}\end{array}$ & $\begin{array}{r}-0.147 * * \\
{[0.050]}\end{array}$ & $\begin{array}{l}0.579 * \\
{[0.272]}\end{array}$ & $\begin{array}{r}1.191 * * \\
{[0.402]}\end{array}$ & $\begin{array}{l}0.531 \dagger \\
{[0.272]}\end{array}$ & $\begin{array}{r}1.126 * * \\
{[0.424]}\end{array}$ \\
\hline Fixed & $\begin{array}{r}-0.043 \\
{[0.056]}\end{array}$ & $\begin{array}{r}-0.051 \\
{[0.080]}\end{array}$ & $\begin{array}{r}-0.043 \\
{[0.060]}\end{array}$ & $\begin{array}{r}0.002 \\
{[0.088]}\end{array}$ & $\begin{array}{r}0.033 \\
{[0.064]}\end{array}$ & $\begin{array}{r}0.028 \\
{[0.086]}\end{array}$ & $\begin{array}{r}0.024 \\
{[0.064]}\end{array}$ & $\begin{array}{r}0.083 \\
{[0.085]}\end{array}$ & $\begin{array}{r}0.013 \\
{[0.283]}\end{array}$ & $\begin{array}{r}0.240 \\
{[0.363]}\end{array}$ & $\begin{array}{r}0.039 \\
{[0.288]}\end{array}$ & $\begin{array}{r}0.289 \\
{[0.463]}\end{array}$ \\
\hline Foreign & $\begin{array}{r}0.052 \\
{[0.046]}\end{array}$ & $\begin{array}{r}0.033 \\
{[0.026]}\end{array}$ & $\begin{array}{r}0.050 \\
{[0.046]}\end{array}$ & $\begin{array}{r}0.035 \\
{[0.032]}\end{array}$ & $\begin{array}{r}0.049 \\
{[0.047]}\end{array}$ & $\begin{array}{r}0.042 \\
{[0.038]}\end{array}$ & $\begin{array}{r}0.048 \\
{[0.048]}\end{array}$ & $\begin{array}{r}0.047 \\
{[0.049]}\end{array}$ & $\begin{array}{r}0.045 \\
{[0.138]}\end{array}$ & $\begin{array}{r}-0.340 \dagger \\
{[0.179]}\end{array}$ & $\begin{array}{r}0.106 \\
{[0.125]}\end{array}$ & $\begin{array}{r}-0.147 \\
{[0.140]}\end{array}$ \\
\hline $\begin{array}{l}\text { Fixed effects } \\
\text { Firm }\end{array}$ & $\mathrm{Y}$ & $Y$ & $\mathrm{Y}$ & $Y$ & $\mathrm{Y}$ & $Y$ & $Y$ & $Y$ & $Y$ & $Y$ & $Y$ & Y \\
\hline $\begin{array}{l}\text { Year } \\
\text { Industry-year }\end{array}$ & $\begin{array}{l}\text { Y } \\
\text { Y }\end{array}$ & $\begin{array}{l}\mathrm{Y} \\
\mathrm{Y} \\
\end{array}$ & $\begin{array}{l}\text { Y } \\
\text { Y }\end{array}$ & $\begin{array}{l}\mathrm{Y} \\
\mathrm{Y} \\
\end{array}$ & $\begin{array}{l}\mathrm{Y} \\
\mathrm{Y} \\
\end{array}$ & $\begin{array}{l}\mathrm{Y} \\
\mathrm{Y} \\
\end{array}$ & $\begin{array}{l}\mathrm{Y} \\
\mathrm{Y} \\
\end{array}$ & $\begin{array}{l}\mathrm{Y} \\
\mathrm{Y} \\
\end{array}$ & $\begin{array}{l}\mathrm{Y} \\
\mathrm{Y} \\
\end{array}$ & $\begin{array}{l}\mathrm{Y} \\
\mathrm{Y} \\
\end{array}$ & $\begin{array}{l}\mathrm{Y} \\
\mathrm{Y} \\
\end{array}$ & $\begin{array}{l}\mathrm{Y} \\
\mathrm{Y}\end{array}$ \\
\hline$N$ (total) & 1,177 & $\begin{array}{l}600 \\
172\end{array}$ & 1,102 & 553 & 1,140 & 590 & 1,068 & 545 & 999 & $\begin{array}{l}501 \\
160\end{array}$ & $\begin{array}{l}946 \\
236\end{array}$ & 468 \\
\hline $\begin{array}{l}N \text { (firms) } \\
R^{2} \text { (within) }\end{array}$ & $\begin{array}{r}266 \\
0.451\end{array}$ & $\begin{array}{r}172 \\
0.563\end{array}$ & $\begin{array}{r}252 \\
0.468\end{array}$ & $\begin{array}{r}161 \\
0.588\end{array}$ & $\begin{array}{r}260 \\
0.417\end{array}$ & $\begin{array}{r}168 \\
0.512\end{array}$ & $\begin{array}{r}246 \\
0.438\end{array}$ & $\begin{array}{r}159 \\
0.519\end{array}$ & $\begin{array}{r}246 \\
0.582\end{array}$ & $\begin{array}{r}160 \\
0.63\end{array}$ & $\begin{array}{r}236 \\
0.573\end{array}$ & $\begin{array}{r}150 \\
0.622\end{array}$ \\
\hline$p(F$ test $)$ & $<0.001$ & $<0.001$ & $<0.001$ & $<0.001$ & $<0.001$ & $<0.001$ & $<0.001$ & $<0.001$ & $<0.001$ & $<0.001$ & $<0.001$ & $<0.001$ \\
\hline
\end{tabular}

$\dagger p<0.10, * p<0.05, * * p<0.01, * * * p<0.001$. Robust standard errors in brackets, clustered on each firm. 
Table 6

Effect of BNDES loans and equity on firm-level financial expenses, capital expenditures, and investments: Fixed-effect regressions

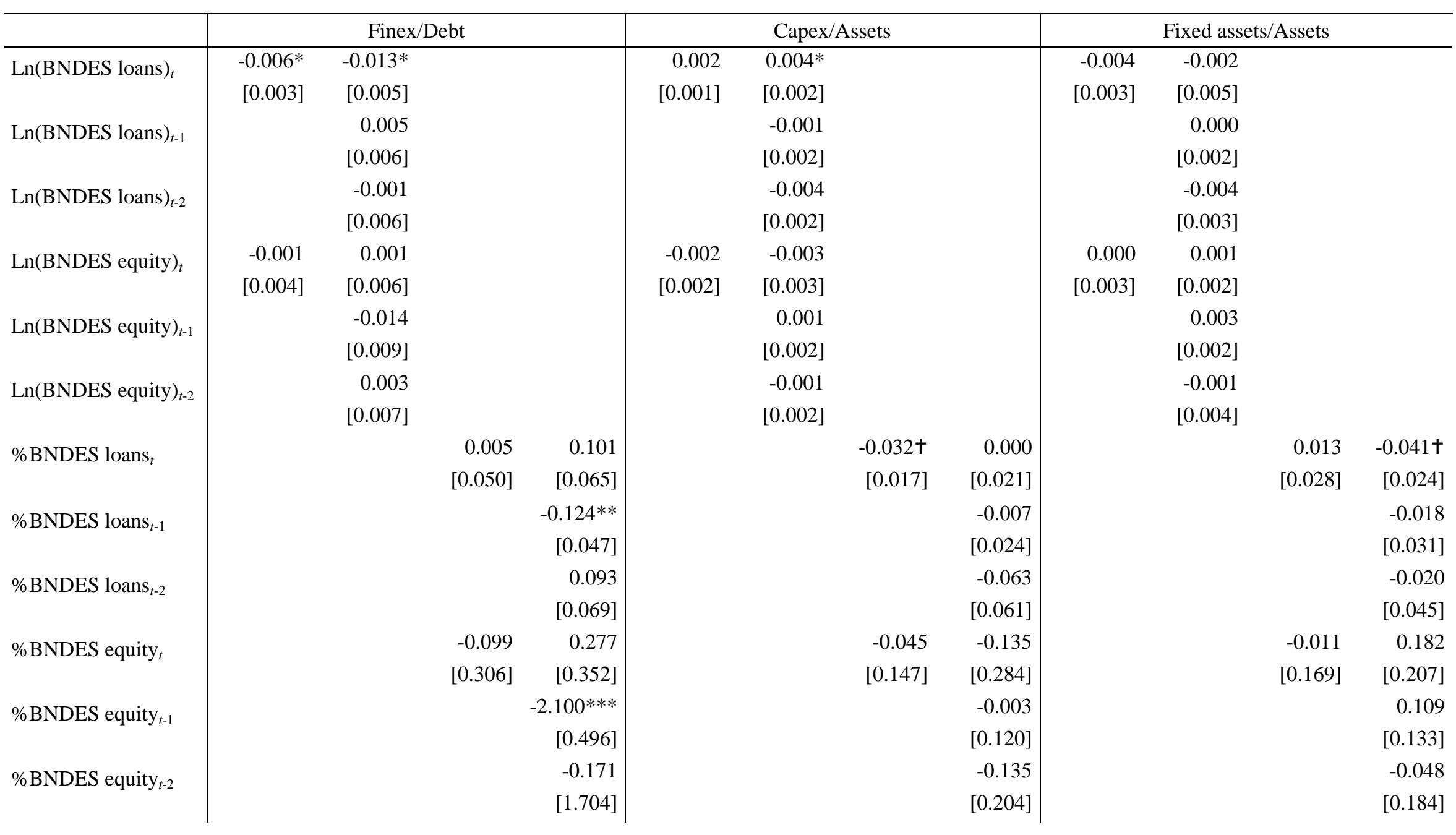




\begin{tabular}{|c|c|c|c|c|c|c|c|c|c|c|c|c|}
\hline Belongs to a group & $\begin{array}{r}-0.080 \\
{[0.054]}\end{array}$ & $\begin{array}{r}0.031 \\
{[0.059]}\end{array}$ & $\begin{array}{r}-0.078 \\
{[0.059]}\end{array}$ & $\begin{array}{r}0.063 \\
{[0.069]}\end{array}$ & $\begin{array}{c}0.045^{*} \\
{[0.020]}\end{array}$ & $\begin{array}{c}-0.007 \\
{[0.027]}\end{array}$ & $\begin{array}{c}0.053^{*} \\
{[0.022]}\end{array}$ & $\begin{array}{r}-0.010 \\
{[0.028]}\end{array}$ & $\begin{array}{r}-0.035 \\
{[0.033]}\end{array}$ & $\begin{array}{r}0.007 \\
{[0.029]}\end{array}$ & $\begin{array}{r}-0.031 \\
{[0.032]}\end{array}$ & $\begin{array}{r}0.015 \\
{[0.025]}\end{array}$ \\
\hline \multirow{2}{*}{ Ln(Assets) } & $0.067 \dagger$ & $0.113^{*}$ & 0.061 & $0.114 *$ & 0.006 & 0.027 & 0.000 & 0.028 & $0.057 \dagger$ & $0.109^{*}$ & $0.079 *$ & $0.101 \dagger$ \\
\hline & [0.039] & [0.054] & [0.041] & {$[0.050]$} & [0.023] & {$[0.031]$} & {$[0.025]$} & {$[0.036]$} & {$[0.031]$} & [0.054] & [0.037] & {$[0.053]$} \\
\hline \multirow{2}{*}{ Leverage } & $-0.483 * * *$ & $-0.596 * * *$ & $-0.500 * * *$ & $-0.613 * * *$ & 0.001 & -0.015 & 0.005 & -0.016 & -0.079 & -0.154 & $-0.115 \dagger$ & $-0.188 \dagger$ \\
\hline & [0.091] & [0.155] & [0.089] & [0.143] & [0.043] & {$[0.056]$} & [0.040] & {$[0.058]$} & {$[0.071]$} & [0.108] & [0.068] & {$[0.096]$} \\
\hline \multirow{2}{*}{ Fixed } & -0.074 & $-0.334 \dagger$ & -0.044 & -0.186 & 0.040 & -0.059 & 0.037 & -0.069 & & & & \\
\hline & {$[0.091]$} & [0.171] & [0.086] & {$[0.148]$} & {$[0.050]$} & {$[0.123]$} & [0.049] & {$[0.148]$} & & & & \\
\hline \multirow{2}{*}{ Foreign } & 0.002 & -0.041 & 0.009 & -0.035 & -0.002 & -0.021 & -0.003 & -0.022 & -0.021 & $-0.038 *$ & -0.018 & -0.020 \\
\hline & [0.044] & [0.034] & {$[0.052]$} & {$[0.052]$} & [0.011] & [0.019] & [0.016] & {$[0.024]$} & {$[0.026]$} & [0.019] & [0.024] & {$[0.016]$} \\
\hline \multicolumn{13}{|l|}{ Fixed effects } \\
\hline Firm & $\mathrm{Y}$ & $\mathrm{Y}$ & $\mathrm{Y}$ & $\mathrm{Y}$ & $\mathrm{Y}$ & $\mathrm{Y}$ & $\mathrm{Y}$ & $\mathrm{Y}$ & $\mathrm{Y}$ & $\mathrm{Y}$ & $\mathrm{Y}$ & $\mathrm{Y}$ \\
\hline Year & $\mathrm{Y}$ & $\mathrm{Y}$ & $\mathrm{Y}$ & $\mathrm{Y}$ & $\mathrm{Y}$ & Y & $\mathrm{Y}$ & $\mathrm{Y}$ & $\mathrm{Y}$ & $\mathrm{Y}$ & $\mathrm{Y}$ & $\mathrm{Y}$ \\
\hline Industry-year & $\mathrm{Y}$ & $\mathrm{Y}$ & $\mathrm{Y}$ & $\mathrm{Y}$ & $\mathrm{Y}$ & $\mathrm{Y}$ & $\mathrm{Y}$ & $\mathrm{Y}$ & $\mathrm{Y}$ & $\mathrm{Y}$ & $\mathrm{Y}$ & $\mathrm{Y}$ \\
\hline$N($ total $)$ & 818 & 422 & 807 & 416 & 1,125 & 582 & 1,057 & 539 & 1,177 & 600 & 1,102 & 553 \\
\hline$N$ (firms) & 211 & 130 & 207 & 129 & 257 & 168 & 244 & 158 & 266 & 172 & 252 & 161 \\
\hline$R^{2}$ (within) & 0.53 & 0.613 & 0.515 & 0.58 & 0.314 & 0.397 & 0.314 & 0.413 & 0.264 & 0.303 & 0.294 & 0.346 \\
\hline$p(F$ test $)$ & $<0.001$ & $<0.001$ & $<0.001$ & $<0.001$ & $<0.001$ & $<0.001$ & $<0.001$ & $<0.001$ & $<0.001$ & $<0.001$ & $<0.001$ & $<0.001$ \\
\hline
\end{tabular}

$\dagger p<0.10, * p<0.05, * * p<0.01, * * * p<0.001$. Robust standard errors in brackets, clustered on each firm. 
Table 7

The effect of variations in BNDES loans (percentage of total debt) on variations in performance and investment indicators: Differences-indifferences matching estimation of average treatment effects for the treated (ATT)

\begin{tabular}{|c|c|c|c|c|c|c|}
\hline & $\triangle \mathrm{ROA}$ & $\triangle$ EBITDA/Assets & $\Delta$ Tobin's q & $\Delta$ Finex/Debt & $\Delta$ Capex/Assets & $\Delta$ Fixed/Assets \\
\hline $\begin{array}{l}\Delta \% \text { BNDES loans }>5 \% \\
\quad \text { ATT }\end{array}$ & $\begin{array}{r}-0.002 \\
{[0.015]}\end{array}$ & $\begin{array}{r}-0.020 \\
{[0.013]}\end{array}$ & $\begin{array}{r}-0.110 \\
{[0.106]}\end{array}$ & $\begin{array}{r}0.032 \\
{[0.033]}\end{array}$ & $\begin{array}{r}-0.014 \\
{[0.010]}\end{array}$ & $\begin{array}{r}0.012 \\
{[0.024]}\end{array}$ \\
\hline $\begin{array}{l}\Delta \% \text { BNDES loans }>10 \% \\
\text { ATT }\end{array}$ & $\begin{array}{r}0.033 \\
{[0.020]}\end{array}$ & $\begin{array}{r}0.016 \\
{[0.015]}\end{array}$ & $\begin{array}{r}0.047 \\
{[0.124]}\end{array}$ & $\begin{array}{r}-0.031 \dagger \\
{[0.018]}\end{array}$ & $\begin{array}{r}-0.016 \\
{[0.013]}\end{array}$ & $\begin{array}{r}0.003 \\
{[0.029]}\end{array}$ \\
\hline $\begin{array}{l}\Delta \% \text { BNDES loans }>15 \% \\
\quad \text { ATT }\end{array}$ & $\begin{array}{r}0.001 \\
{[0.022]}\end{array}$ & $\begin{array}{r}-0.018 \\
{[0.020]}\end{array}$ & $\begin{array}{r}0.330 \\
{[0.216]}\end{array}$ & $\begin{array}{r}-0.045^{*} \\
{[0.022]}\end{array}$ & $\begin{array}{r}-0.006 \\
{[0.015]}\end{array}$ & $\begin{array}{r}-0.010 \\
{[0.040]}\end{array}$ \\
\hline$N$ & 110 & 105 & 78 & 60 & 105 & 110 \\
\hline
\end{tabular}

$\dagger p<0.10, * p<0.05, * * p<0.01, * * * p<0.001$. Standard errors are in brackets. We adopt the bias-corrected matching estimator proposed by Abadie and colleagues $(2004,2011)$. We allow one matching observation per treated firm, imposing exact matching for year and industry classification. For any given year, $t$, pre-treatment measures are computed as averages in the period between $t-3$ and $t-1$, whereas post-treatment measures are computed as averages in the period between $t+1$ and $t+3$. Besides industry and year, other observable matching variables include the pre-treatment levels of Ln(Assets), Leverage, and dummies coding type of ownership and whether the firm belongs to a group as well as pre-treatment levels of the outcome variable of interest (for instance, in the estimation of the ATT for $\Delta$ ROA, we also consider as a matching variable the level of ROA in the pre-treatment period). 
Table 8

Effect of BNDES loans and equity on firm-level financial constraints: Fixed-effect regressions

\begin{tabular}{|c|c|c|c|c|}
\hline & (Capex & $\begin{array}{r}\text { Investm } \\
\text { Stock of fix }\end{array}$ & $\begin{array}{l}\text { ent } \\
\text { ed assets in }\end{array}$ & $t-1)$ \\
\hline Cash flow & $0.028 *$ & $0.059 * *$ & $0.027 *$ & $0.046^{* * *}$ \\
\hline & {$[0.012]$} & [0.019] & {$[0.011]$} & [0.013] \\
\hline$\%$ BNDES loans $_{t}$ & -22.642 & -17.365 & & \\
\hline & {$[14.154]$} & {$[12.775]$} & & \\
\hline$\%$ BNDES equity ${ }_{t}$ & -523.029 & -474.118 & & \\
\hline & [425.345] & {$[351.557]$} & & \\
\hline $\operatorname{Ln}(\mathrm{BNDES} \text { loans })_{t}$ & & & -0.688 & -0.262 \\
\hline & & & [0.996] & [0.979] \\
\hline $\operatorname{Ln}(\text { BNDES equity })_{t}$ & & & -5.130 & -4.451 \\
\hline & & & [5.003] & [4.093] \\
\hline Cash flow $\times \%$ BNDES loans ${ }_{t}$ & & -0.057 & & \\
\hline & & {$[0.123]$} & & \\
\hline Cash flow $x \%$ BNDES equity ${ }_{t}$ & & -0.382 & & \\
\hline & & [0.243] & & \\
\hline Cash flow $\times \operatorname{Ln}(\text { BNDES loans })_{t}$ & & & & 0.000 \\
\hline & & & & {$[0.003]$} \\
\hline Cash flow $\times \operatorname{Ln}(\text { BNDES equity })_{t}$ & & & & -0.008 \\
\hline & & & & [0.006] \\
\hline Tobin’s q & 10.631 & 5.419 & 10.727 & 6.493 \\
\hline & [13.280] & [11.355] & {$[12.283]$} & [10.651] \\
\hline Belongs to a group & -2.582 & 1.234 & -2.400 & 2.621 \\
\hline & {$[14.752]$} & {$[14.231]$} & {$[12.295]$} & [11.044] \\
\hline Ln(Assets) & $33.869 \dagger$ & 24.079 & $28.791 *$ & $25.407 \dagger$ \\
\hline & {$[17.818]$} & [19.612] & [12.107] & [14.124] \\
\hline Leverage & 7.884 & 9.967 & 14.813 & 9.832 \\
\hline & [43.612] & [52.722] & [32.494] & [38.489] \\
\hline Foreign & 24.292 & 27.746 & 20.457 & 24.693 \\
\hline & [19.389] & [23.735] & [19.841] & [25.444] \\
\hline Fixed effects & & & & \\
\hline Firm & Y & $\mathrm{Y}$ & $\mathrm{Y}$ & Y \\
\hline Year & $\mathrm{Y}$ & $\mathrm{Y}$ & $\mathrm{Y}$ & $\mathrm{Y}$ \\
\hline Industry-year & $\mathrm{Y}$ & $\mathrm{Y}$ & Y & Y \\
\hline$N($ total $)$ & 741 & 741 & 783 & 783 \\
\hline$N$ (firms) & 192 & 192 & 201 & 201 \\
\hline$p(F$ test $)$ & $<0.001$ & $<0.001$ & $<0.001$ & $<0.001$ \\
\hline
\end{tabular}


Table 9

Determinants of BNDES's loans: Fixed-effect regressions

\begin{tabular}{|c|c|c|c|c|c|c|c|c|c|c|c|c|}
\hline & \multicolumn{6}{|c|}{$\begin{array}{l}\text { Effect of performance variables: } \\
\text { (a) ROA, (b) EBITDA/Assets, (c) Tobin's q }\end{array}$} & \multicolumn{6}{|c|}{$\begin{array}{l}\text { Effect of donation variables, based on margins of victory: } \\
\text { President, government, senator: (a) } 2 \% \text {, (b) } 5 \% \text {, (c) } 10 \% \text { of votes; } \\
\text { deputies: (a) } 10, \text { (b) } 25 \text {, (c) } 100 \text { thousand votes }\end{array}$} \\
\hline & \multicolumn{3}{|c|}{ Ln(BNDES loans) } & \multicolumn{3}{|c|}{$\%$ BNDES loans } & \multicolumn{3}{|c|}{ Ln(BNDES loans $)$} & \multicolumn{3}{|c|}{$\%$ BNDES loans } \\
\hline & (a) & (b) & (c) & (a) & (b) & (c) & (a) & (b) & (c) & (a) & (b) & (c) \\
\hline \multirow[t]{2}{*}{ Performance $_{t}$} & 0.927 & 1.456 & 0.136 & $0.198 \dagger$ & $0.204 \dagger$ & 0.036 & & & & & & \\
\hline & [1.463] & {$[1.362]$} & {$[0.271]$} & {$[0.115]$} & [0.119] & {$[0.027]$} & & & & & & \\
\hline \multirow[t]{2}{*}{ Performance $_{t-1}$} & $2.849 \dagger$ & 2.140 & 0.245 & 0.138 & 0.108 & 0.047 & & & & & & \\
\hline & [1.670] & {$[1.625]$} & {$[0.210]$} & [0.118] & {$[0.124]$} & {$[0.030]$} & & & & & & \\
\hline \multirow[t]{2}{*}{ Performance $_{t-2}$} & 0.671 & 1.735 & 0.322 & 0.173 & $0.210 \dagger$ & -0.020 & & & & & & \\
\hline & {$[1.540]$} & {$[1.764]$} & {$[0.332]$} & {$[0.107]$} & {$[0.117]$} & {$[0.027]$} & & & & & & \\
\hline \multicolumn{13}{|l|}{ Number of winning candidates: } \\
\hline \multirow[t]{2}{*}{ President, senator, governor } & & & & & & & -0.140 & 0.236 & $0.332 \dagger$ & $-0.054 \dagger$ & -0.020 & 0.001 \\
\hline & & & & & & & [0.228] & [0.192] & {$[0.170]$} & {$[0.028]$} & [0.024] & [0.019] \\
\hline \multirow[t]{2}{*}{ Deputies } & & & & & & & $0.560 *$ & $0.277^{*}$ & $0.169 *$ & $0.062 *$ & $0.027 *$ & $0.018+$ \\
\hline & & & & & & & {$[0.246]$} & {$[0.111]$} & {$[0.076]$} & {$[0.031]$} & {$[0.013]$} & {$[0.009]$} \\
\hline \multicolumn{13}{|l|}{ Number of losing candidates: } \\
\hline \multirow[t]{2}{*}{ President, senator, governor } & & & & & & & -0.480 & $-1.030 \dagger$ & -0.341 & -0.041 & -0.076 & -0.032 \\
\hline & & & & & & & {$[0.433]$} & {$[0.590]$} & {$[0.315]$} & {$[0.070]$} & {$[0.056]$} & [0.031] \\
\hline \multirow[t]{2}{*}{ Deputies } & & & & & & & $-0.524 * *$ & $-0.215^{*}$ & $-0.159 *$ & $-0.044 \dagger$ & -0.014 & -0.010 \\
\hline & & & & & & & [0.187] & {$[0.083]$} & {$[0.078]$} & {$[0.024]$} & [0.009] & [0.009] \\
\hline \multirow[t]{2}{*}{ Belongs to a group } & -0.580 & -0.816 & -1.816 & 0.047 & 0.041 & 0.040 & $1.721 \dagger$ & $1.796 \dagger$ & $1.833+$ & 0.155 & 0.162 & 0.167 \\
\hline & {$[1.612]$} & {$[1.547]$} & {$[2.566]$} & {$[0.080]$} & {$[0.078]$} & {$[0.118]$} & {$[0.900]$} & {$[0.958]$} & {$[0.979]$} & {$[0.113]$} & {$[0.108]$} & {$[0.106]$} \\
\hline \multirow[t]{2}{*}{ Ln(Assets) } & 0.193 & 0.383 & 0.229 & -0.038 & -0.048 & 0.017 & 0.294 & 0.432 & 0.681 & 0.011 & 0.032 & 0.052 \\
\hline & {$[0.767]$} & {$[0.759]$} & {$[0.901]$} & {$[0.063]$} & {$[0.065]$} & {$[0.089]$} & {$[0.766]$} & [0.779] & [0.798] & [0.107] & {$[0.112]$} & [0.116] \\
\hline \multirow[t]{2}{*}{ Leverage } & $5.795 * * *$ & $4.905^{* *}$ & $5.216^{* *}$ & -0.142 & -0.217 & -0.274 & 3.694 & $4.220 t$ & $4.472 \dagger$ & -0.643 & -0.590 & -0.545 \\
\hline & [1.684] & {$[1.561]$} & {$[1.780]$} & [0.132] & [0.137] & {$[0.194]$} & [2.239] & [2.346] & [2.403] & [0.421] & [0.419] & [0.402] \\
\hline
\end{tabular}




\begin{tabular}{|c|c|c|c|c|c|c|c|c|c|c|c|c|}
\hline \multirow[t]{2}{*}{ Fixed } & -1.381 & -2.529 & -0.684 & 0.034 & -0.032 & 0.038 & 2.040 & 0.964 & 2.194 & 0.291 & 0.214 & 0.231 \\
\hline & [3.439] & [3.718] & [3.880] & [0.182] & [0.197] & {$[0.263]$} & [3.425] & [2.735] & [3.184] & [0.308] & [0.291] & [0.316] \\
\hline \multirow[t]{2}{*}{ Foreign } & -1.860 & -1.828 & -4.650 & 0.013 & 0.013 & $-0.169 \dagger$ & $3.959 \dagger$ & $4.078 \dagger$ & $4.304 \dagger$ & 0.062 & 0.077 & 0.091 \\
\hline & [1.997] & [1.975] & [3.079] & [0.112] & [0.109] & [0.094] & [2.027] & [2.144] & {$[2.175]$} & [0.110] & [0.095] & [0.089] \\
\hline \multicolumn{13}{|l|}{ Fixed effects } \\
\hline Firm & $\mathrm{Y}$ & $\mathrm{Y}$ & $\mathrm{Y}$ & $\mathrm{Y}$ & $\mathrm{Y}$ & $\mathrm{Y}$ & $\mathrm{Y}$ & $\mathrm{Y}$ & $\mathrm{Y}$ & $\mathrm{Y}$ & $\mathrm{Y}$ & $\mathrm{Y}$ \\
\hline Year & $\mathrm{Y}$ & $\mathrm{Y}$ & $\mathrm{Y}$ & $\mathrm{Y}$ & $\mathrm{Y}$ & $\mathrm{Y}$ & $\mathrm{Y}$ & $\mathrm{Y}$ & $\mathrm{Y}$ & $\mathrm{Y}$ & Y & $\mathrm{Y}$ \\
\hline Industry-year & $\mathrm{Y}$ & $\mathrm{Y}$ & $\mathrm{Y}$ & $\mathrm{Y}$ & $\mathrm{Y}$ & $\mathrm{Y}$ & $\mathrm{Y}$ & $\mathrm{Y}$ & $\mathrm{Y}$ & $\mathrm{Y}$ & $\mathrm{Y}$ & $\mathrm{Y}$ \\
\hline$N($ total $)$ & 915 & 869 & 703 & 852 & 808 & 666 & 416 & 416 & 416 & 387 & 387 & 387 \\
\hline$N$ (firms) & 216 & 206 & 184 & 205 & 197 & 179 & 113 & 113 & 113 & 106 & 106 & 106 \\
\hline$R^{2}$ (within) & 0.332 & 0.35 & 0.392 & 0.369 & 0.369 & 0.412 & 0.565 & 0.572 & 0.565 & 0.406 & 0.4 & 0.398 \\
\hline$p(F$ test $)$ & $<0.001$ & $<0.001$ & $<0.001$ & $<0.001$ & $<0.001$ & $<0.001$ & $<0.001$ & $<0.001$ & $<0.001$ & $<0.001$ & $<0.001$ & $<0.001$ \\
\hline
\end{tabular}

$\dagger p<0.10, * p<0.05, * * p<0.01, * * * p<0.001$. Robust standard errors in brackets, clustered on each firm. 
Table 10

Determinants of BNDES's equity: Fixed-effect regressions

\begin{tabular}{|c|c|c|c|c|c|c|c|c|c|c|c|c|}
\hline & \multicolumn{6}{|c|}{$\begin{array}{l}\text { Effect of performance variables: } \\
\text { (a) ROA, (b) EBITDA/Assets, (c) Tobin's q }\end{array}$} & \multicolumn{6}{|c|}{$\begin{array}{l}\text { Effect of donation variables, based on margins of victory: } \\
\text { President, government, senator: (a) } 2 \%, \text { (b) } 5 \% \text {, (c) } 10 \% \text { of votes; } \\
\text { deputies: (a) } 10 \text {, (b) } 25 \text {, (c) } 100 \text { thousand votes }\end{array}$} \\
\hline & \multicolumn{3}{|c|}{ Ln(BNDES loans) } & \multicolumn{3}{|c|}{ \%BNDES loans } & \multicolumn{3}{|c|}{ Ln(BNDES loans) } & \multicolumn{3}{|c|}{ \%BNDES loans } \\
\hline & (a) & (b) & (c) & (a) & (b) & (c) & (a) & (b) & (c) & (a) & (b) & (c) \\
\hline \multirow[t]{2}{*}{ Performance $_{t}$} & -0.506 & 0.274 & -0.2 & 0.005 & 0.008 & -0.001 & & & & & & \\
\hline & {$[0.789]$} & {$[0.904]$} & {$[0.155]$} & [0.011] & {$[0.011]$} & {$[0.002]$} & & & & & & \\
\hline \multirow[t]{2}{*}{ Performance $_{t-1}$} & -0.61 & -1.025 & -0.252 & 0.004 & -0.002 & -0.003 & & & & & & \\
\hline & [1.007] & {$[1.323]$} & {$[0.172]$} & {$[0.015]$} & {$[0.018]$} & {$[0.002]$} & & & & & & \\
\hline \multirow{2}{*}{ Performance $_{t-2}$} & 0.096 & 0.201 & -0.289 & -0.010 & -0.020 & $-0.007 \dagger$ & & & & & & \\
\hline & {$[1.288]$} & [1.472] & {$[0.182]$} & {$[0.013]$} & [0.017] & {$[0.004]$} & & & & & & \\
\hline \multirow{3}{*}{$\begin{array}{l}\text { Number of winning candidates: } \\
\text { President, senator, governor }\end{array}$} & & & & & & & & & & & & \\
\hline & & & & & & & -0.045 & -0.113 & 0.042 & 0.000 & -0.002 & 0.000 \\
\hline & & & & & & & {$[0.318]$} & {$[0.300]$} & [0.264] & {$[0.004]$} & {$[0.003]$} & [0.003] \\
\hline \multirow[t]{2}{*}{ Deputies } & & & & & & & -0.267 & -0.002 & 0.082 & $-0.006 \dagger$ & -0.001 & 0.000 \\
\hline & & & & & & & {$[0.250]$} & {$[0.131]$} & [0.084] & {$[0.004]$} & {$[0.002]$} & [0.001] \\
\hline \multicolumn{13}{|l|}{ Number of losing candidates: } \\
\hline \multirow[t]{2}{*}{ President, senator, governor } & & & & & & & -1.105 & -1.003 & $-0.913^{* *}$ & -0.019 & $-0.023 t$ & $-0.013 * * * *$ \\
\hline & & & & & & & [1.931] & [1.238] & {$[0.347]$} & {$[0.022]$} & {$[0.013]$} & {$[0.003]$} \\
\hline \multirow[t]{2}{*}{ Deputies } & & & & & & & 0.097 & -0.044 & -0.054 & 0.002 & 0.000 & -0.001 \\
\hline & & & & & & & {$[0.184]$} & {$[0.080]$} & [0.081] & {$[0.002]$} & {$[0.001]$} & [0.001] \\
\hline \multirow[t]{2}{*}{ Belongs to a group } & -0.199 & -0.259 & -1.505 & -0.007 & -0.007 & -0.032 & 0.188 & 0.110 & 0.101 & 0.001 & 0.000 & 0.000 \\
\hline & [0.367] & [0.363] & [1.205] & [0.007] & [0.007] & [0.022] & {$[0.288]$} & [0.299] & [0.294] & {$[0.003]$} & [0.003] & [0.003] \\
\hline \multirow[t]{2}{*}{ Ln(Assets) } & 0.263 & 0.290 & 0.094 & 0.005 & 0.006 & 0.008 & -1.468 & -1.522 & -1.353 & -0.009 & -0.009 & -0.008 \\
\hline & {$[0.328]$} & [0.424] & {$[0.474]$} & [0.006] & [0.007] & [0.009] & [1.098] & [1.141] & [1.114] & [0.010] & [0.010] & [0.010] \\
\hline \multirow[t]{2}{*}{ Leverage } & 0.246 & 0.380 & 0.691 & 0.005 & 0.004 & 0.007 & -1.556 & -1.743 & -1.254 & -0.018 & -0.022 & -0.013 \\
\hline & {$[0.858]$} & [1.032] & [1.423] & {$[0.016]$} & [0.019] & {$[0.028]$} & [1.969] & [1.872] & {$[2.014]$} & {$[0.020]$} & [0.019] & {$[0.023]$} \\
\hline
\end{tabular}




\begin{tabular}{|c|c|c|c|c|c|c|c|c|c|c|c|c|}
\hline Fixed & 0.437 & 0.496 & 0.357 & 0.029 & 0.033 & 0.041 & 1.642 & -0.012 & -0.296 & 0.014 & -0.02 & -0.012 \\
\hline \multirow{3}{*}{ Foreign } & [1.201] & [1.326] & [1.478] & {$[0.022]$} & {$[0.024]$} & {$[0.026]$} & [4.072] & [3.689] & [3.964] & {$[0.035]$} & {$[0.029]$} & {$[0.030]$} \\
\hline & 1.227 & 1.232 & 2.442 & 0.028 & 0.029 & 0.052 & 0.423 & 0.188 & 0.149 & 0.004 & -0.001 & 0.000 \\
\hline & [1.134] & [1.132] & [2.014] & {$[0.024]$} & {$[0.023]$} & {$[0.035]$} & {$[0.523]$} & [0.488] & {$[0.457]$} & {$[0.005]$} & [0.004] & [0.004] \\
\hline Firm & $\mathrm{Y}$ & $\mathrm{Y}$ & $\mathrm{Y}$ & $\mathrm{Y}$ & $\mathrm{Y}$ & $\mathrm{Y}$ & $\mathrm{Y}$ & $\mathrm{Y}$ & $\mathrm{Y}$ & $\mathrm{Y}$ & $\mathrm{Y}$ & $\mathrm{Y}$ \\
\hline Year & $\mathrm{Y}$ & $\mathrm{Y}$ & $\mathrm{Y}$ & $\mathrm{Y}$ & $\mathrm{Y}$ & $\mathrm{Y}$ & $\mathrm{Y}$ & $\mathrm{Y}$ & $\mathrm{Y}$ & $\mathrm{Y}$ & $\mathrm{Y}$ & $\mathrm{Y}$ \\
\hline Industry-year & $\mathrm{Y}$ & $\mathrm{Y}$ & $\mathrm{Y}$ & Y & $\mathrm{Y}$ & Y & $\mathrm{Y}$ & $\mathrm{Y}$ & Y & $\mathrm{Y}$ & $\mathrm{Y}$ & $\mathrm{Y}$ \\
\hline$R^{2}$ (within) & 0.338 & 0.341 & 0.383 & 0.415 & 0.411 & 0.442 & 0.169 & 0.179 & 0.234 & 0.412 & 0.42 & 0.452 \\
\hline$p(F$ test $)$ & $<0.001$ & $<0.001$ & $<0.001$ & $<0.001$ & $<0.001$ & $<0.001$ & $<0.001$ & $<0.001$ & $<0.001$ & $<0.001$ & $<0.001$ & $<0.001$ \\
\hline
\end{tabular}

$+p<0.10, * p<0.05, * * p<0.01, * * * p<0.001$. Robust standard errors in brackets, clustered on each firm. 


\section{Endnotes}

${ }^{1}$ For instance, Dinç (2005) finds that, during election years, the lending activity of government-owned banks in
emerging markets is greater than that of private banks. Cole (2009) also finds that lending cycles of agricultural loans in India follow election cycles. Sapienza (2004) shows that, in Italy, the performance of the ruling party in elections affects the lending behavior of state-owned banks. Bailey, Huang, and Yang's (2011) study using Chinese data and Khwaja and Mian's (2005) examination of lending activity in Pakistan found a negative selection of firms with poor performance requesting or receiving loans from state-owned banks.

${ }^{2}$ Carvalho (2010) studies the criteria for the allocation of loans and finds, consistent with our finding, that firms in regions governed by politicians allied with the federal government receive more funding from BNDES. However, he uses aggregate industry-level data instead of firm-level data.

${ }^{3}$ It is also possible that non-listed firms, which are less transparent, would display a higher incidence of opaque deals supporting bailouts and lending based on political criteria. Yet, as in Claessens et al. (2008), we do reveal political effects (through campaign donations) even in this restricted subset of listed companies.

${ }^{4}$ Data available in

〈http://www.bndes.gov.br/SiteBNDES/bndes/bndes_pt/Institucional/Relacao_Com_Investidores/Desempenho/> (accessed in August 8, 2014).

${ }^{5}$ For instance, Ottaviano and Sousa (2007) find that although some BNDES credit lines positively affect productivity, other lines have a negative effect. In another study, Sousa (2010) reports an overall null effect of those loans on productivity. Coelho and De Negri (2010) find that loans have a larger effect on more productive firms. De Negri et al. (2011) find an effect of loans on employment and exports, but not on productivity. It is also possible that non-listed firms, which are less transparent, would display a higher incidence of opaque deals supporting bailouts and lending based on political criteria.

${ }^{6}$ BNDES can provide the loans directly ("first-tier operations") or indirectly ("second-tier operations") through financial intermediaries, such as private and public banks. In both cases, however, loans are associated with the TJLP rate plus a spread that is paid to BNDES if the operation is direct or to the financial intermediary if the operation is indirect. Furthermore, the majority of firms in our sample are large corporations that are eligible to obtain loans directly from BNDES.

${ }^{7}$ Although our sample has over 100 firms receiving loans every year, the top 20 firms have the largest share of loans. In 2009 alone, the top 20 firms in our sample took around 20\% of the total loans from BNDES and $87 \%$ of the new loans to firms in our sample. 


\footnotetext{
${ }^{8}$ We also have a control related to whether the firm is state-owned or private; however, because there was no instance of privatization in our sample, this aspect is automatically controlled for in our fixed-effect regressions.

${ }^{9}$ We code industries at the two-digit SIC level because we would otherwise have few representative firms per industry. Note that our firm-level fixed effects already control for (invariant) industry membership effects.

${ }^{10}$ To allow for lagged effects of loans on outcome variables, we compute post-treatment loans as averages in the period between $t$ and $t+2$.
}

${ }^{11}$ Again, we consider industry classification at the two-digit SIC level. With a more detailed industry classification, we would have few exact matches per firm.

${ }^{12}$ We performed several additional tests to see if the effect of the BNDES variables on performance and investment vary according to certain firm-level traits (results not reported here, but available upon request). Using Ln(Assets), we split the sample (at the median) to compare the effect on smaller and larger firms; using the difference between ROA and the median industry ROA, we do the same to detect possible distinct effects for high- and low-performers. We found no substantial distinct effects. To see if the effect of allocations is larger for firms with high capital-intensity, we also interact the BNDES variables with a dummy coded as one if observed capital expenditures are above the median and zero otherwise. In addition, following Rajan and Zingales (1996), we test if BNDES loans and equity investments have a significantly different effect on performance and investment in firms with higher finance-dependence. For that purpose, we created a variable computed as the difference between capital expenditures and EBITDA, divided by capital expenditures. We then interacted this measure with our BNDES loan and equity variables and found that these interactions were not significant. Finally, we checked if our results hold without winsorizing and using other cutoff levels (5/95\% and 10/90\%). Without winsorizing, results are similar. Winsorizing and using the other cutoff levels, we find some significant effect of loans and equity on Tobin's q. However, the effect is negative and not consistent across specifications. Because this result also rejects the hypothesis that there will be a positive effect on Tobin's q (as per the industrial policy view), our previous conclusions hold.

${ }^{13}$ Unfortunately we could not directly test this conjecture because in our database we do not have fine-grained data on the amount of money donated to candidates; we only have data on the number of candidates who received donations.

${ }^{14}$ Being large, all of our firms are to various degrees involved in political activity. Thus, we cannot really infer whether the donation for a particular candidate resulted in more loans or not. Furthermore, even considering candidates elected by a small margin, we have few firms that, say, only donated to candidates who barely lost the 
election. For instance, in the case of donations for president, governor and senator, we only have 8 observations (firm-years) where all candidates lost and none won by a margin of $2 \%$. This means that in our data most firms have donated to a mix of winning and losing candidates.

${ }^{15}$ The fact that BNDES sometimes prefers to finance firms through convertible bonds could indicate that its way of providing funding follows the kind of incentives that Rodrik (2004) wants in industrial policy. The company has an objective and promises an amortization rate for the debt. If it does not meet those targets, BNDES can dilute current owners by converting its debts to equity at a pre-fixed price. Yet, the conversion of debt to equity is not really a punishment for two reasons. First, even if it dilutes the cash-flow rights of all shareholders, it does not necessarily dilute control as long as firms retain substantial voting rights. Second, even if controlling and minority shareholders lose some of their cash flow when BNDES enters as a new shareholder, they usually have the first right to buy shares in the new equity issue, thus reducing the dilution effect. Convertible loans (or debentures) may therefore act more as a bailout mechanism than as a punishment for failing to meet specific goals. 